Illinois State University

ISU ReD: Research and eData

Theses and Dissertations

$7-8-2020$

\title{
The Influence of Instructor Mental Illness Disclosure on the Perceptions of Mental Illness, Classroom Climate, Teacher Credibility, Homophily, and Social Attraction
}

Kirsten L. Bridgemen

Illinois State University, kirstenbridgemen@gmail.com

Follow this and additional works at: https://ir.library.illinoisstate.edu/etd

Part of the Communication Commons, Higher Education Administration Commons, Higher Education and Teaching Commons, and the Psychiatric and Mental Health Commons

\section{Recommended Citation}

Bridgemen, Kirsten L., "The Influence of Instructor Mental Illness Disclosure on the Perceptions of Mental Illness, Classroom Climate, Teacher Credibility, Homophily, and Social Attraction" (2020). Theses and Dissertations. 1278.

https://ir.library.illinoisstate.edu/etd/1278

This Thesis is brought to you for free and open access by ISU ReD: Research and eData. It has been accepted for inclusion in Theses and Dissertations by an authorized administrator of ISU ReD: Research and eData. For more information, please contact ISUReD@ilstu.edu. 


\section{THE INFLUENCE OF INSTRUCTOR MENTAL ILLNESS DISCLOSURE ON THE PERCEPTIONS OF MENTAL ILLNESS, CLASSROOM CLIMATE, TEACHER CREDIBILITY, HOMOPHILY, AND SOCIAL ATTRACTION}

\section{KIRSTEN L. BRIDGEMEN}

96 Pages

This study uses the lens of Communication Privacy Management theory to analyze the impact an instructor's depth of disclosure of their mental illness can have on mental illness stigmatization, classroom climate, as well as teacher credibility, homophily, and social attraction. Participants responded to a series of quantitative-based questions regarding a hypothetical syllabus with varied levels of a teacher disclosing their mental illness. Results indicated that none of the investigated dependent variables were negatively affected by the hypothetical instructor's disclosure, and mental illness stigmatization was lessened. Implications, limitations, and areas for future research are discussed.

KEYWORDS: Communication Privacy Management theory, instructor disclosure, mental illness, stigmatization, classroom climate, teacher credibility, homophily, social attraction 
THE INFLUENCE OF INSTRUCTOR MENTAL ILLNESS DISCLOSURE ON THE PERCEPTIONS OF MENTAL ILLNESS, CLASSROOM CLIMATE, TEACHER CREDIBILITY, HOMOPHILY, AND SOCIAL ATTRACTION

KIRSTEN L. BRIDGEMEN

A Thesis Submitted in Partial Fulfillment of the Requirements for the Degree of MASTER OF SCIENCE

School of Communication

ILLINOIS STATE UNIVERSITY 
(C) 2020 Kirsten L. Bridgemen 
THE INFLUENCE OF INSTRUCTOR MENTAL ILLNESS DISCLOSURE ON THE PERCEPTIONS OF MENTAL ILLNESS, CLASSROOM CLIMATE, TEACHER CREDIBILITY, HOMOPHILY, AND SOCIAL ATTRACTION

KIRSTEN L. BRIDGEMEN

COMMITTEE MEMBERS:

John F. Hooker, Co-chair

Cheri J. Simonds, Co-chair

Kevin R. Meyer 


\section{ACKNOWLEDGMENTS}

First and foremost, I'd like to thank my committee for all of their dedication and assistance in this project. This project would not have been born if it weren't for Dr. Simonds' class in my first semester of graduate school. She was foundational in the inception of this project, and I'm forever grateful for her efforts in inspiring those in higher education. Dr. Simonds, thank you for being a role model for women in the workplace, especially to those working in academia, and for your significant insights with my thesis. Further, my efforts in this project would have been futile without the help and guidance I received from Dr. Hooker. For the countless meetings, dozens of emails, and nit-picky questions you fielded from me, thank you for making this experience manageable, Dr. Hooker. Dr. Meyer, thank you for your thoughtful questioning and diligence with my drafts, as this feedback truly helped to challenge my thought process in both this project and my academic career.

To my cohort buddies: I love and miss you dearly. Many of you are the reason I survived graduate school, so thank you for the all-nighters, the brainstorm sessions, the wine nights, and the car rides filled with tears and laughter. I'm so grateful for the time we've spent together.

To all of those reading with mental health challenges, this project was, and will always be, for you. You are not alone, and I hope that this small effort can help to de-stigmatize numerous related experiences in the classroom and beyond.

K. L. B. 


\section{CONTENTS}

Page

ACKNOWLEDGMENTS

TABLES $\quad$ V

CHAPTER I: LITERATURE REVIEW

Mental Health and Mental Illness 3

Stigmatizations of Mental Illness $\quad 4$

Combatting the Stigma $\quad 5$

$\begin{array}{ll}\text { Disclosure in the Classroom } & 6\end{array}$

$\begin{array}{ll}\text { Communication Privacy Management Theory } & 7\end{array}$

$\begin{array}{ll}\text { Instructor Self-Disclosure } & 10\end{array}$

Instructor Disclosure of Mental Illness $\quad 12$

$\begin{array}{ll}\text { Classroom Climate } & 15\end{array}$

$\begin{array}{ll}\text { First Day of Class } & 16\end{array}$

$\begin{array}{ll}\text { The Syllabus } & 16\end{array}$

$\begin{array}{ll}\text { Instructor Credibility } & 18\end{array}$

$\begin{array}{ll}\text { Instructor-Student Relationship } & 20\end{array}$

$\begin{array}{ll}\text { Homophily } & 20\end{array}$

$\begin{array}{ll}\text { Social Attraction } & 21\end{array}$

$\begin{array}{ll}\text { Research Questions } & 22\end{array}$

$\begin{array}{ll}\text { CHAPTER II: METHODS } & 24\end{array}$

$\begin{array}{ll}\text { Participants } & 24\end{array}$

$\begin{array}{ll}\text { Materials } & 24\end{array}$ 
Measures

Procedures

CHAPTER III: RESULTS

CHAPTER IV: DISCUSSION

Summary of Findings $\quad 35$

$\begin{array}{ll}\text { Implications } & 38\end{array}$

$\begin{array}{ll}\text { Practical Implications } & 38\end{array}$

Theoretical Implications $\quad 39$

$\begin{array}{ll}\text { Limitations } & 41\end{array}$

Limits to the Medium $\quad 41$

Limits to the Demographics $\quad 41$

Limits to the Materials $\quad 43$

Directions for Future Research $\quad 44$

General, Variable-Based Directions $\quad 44$

Demographic-Focused Directions $\quad 44$

Replication of Study $\quad 45$

$\begin{array}{ll}\text { Conclusion } & 47\end{array}$

$\begin{array}{ll}\text { REFERENCES } & 48\end{array}$

APPENDIX A: "NO DISCLOSURE SYLLABUS” STIMULUS (NULL STIMULUS) 73

APPENDIX B: "PARTIAL DISCLOSURE SYLLABUS” STIMULUS 75

APPENDIX C: "FULL DISCLOSURE SYLLABUS” STIMULUS 77

APPENDIX D: NO DISCLOSURE STIMULUS MANIPULATION CHECK FORM 79

APPENDIX E: PARTIAL DISCLOSURE STIMULUS MANIPULATION CHECK FORM 80 
APPENDIX F: FULL DISCLOSURE STIMULUS MANIPULATION CHECK FORM

APPENDIX G: DEMOGRAPHICS QUESTIONNAIRE

APPENDIX H: MENTAL ILLNESS PERCEPTIONS QUESTIONNAIRE

APPENDIX I: CLASSROOM CLIMATE (TEACHER-STUDENT INTERACTIONS)

QUESTIONNAIRE

APPENDIX J: CLASSROOM CLIMATE (ATMOSPHERE) QUESTIONNAIRE

APPENDIX K: TEACHER CREDIBILITY QUESTIONNAIRE

APPENDIX L: BACKGROUND HOMOPHILY QUESTIONNAIRE

APPENDIX M: ATTITUDE HOMOPHILY QUESTIONNAIRE 


\section{TABLES}

Table Page

1. Descriptive Statistics 33

2. Bivariate Correlations among Scales for All Variables 34 


\section{CHAPTER I: LITERATURE REVIEW}

Mental health and mental illness have gained prominence in national conversations in the past few years, notably in the classroom setting (Goldman, 2018; Rudick \& Dannels, 2018;

Simonds \& Hooker, 2018; Smith \& Applegate, 2018). Although several scholars have examined students' disclosure of their mental illness in the classroom (Brown, Moloney, \& Brown, 2018; Corrigan et al., 2016; Simonds \& Hooker, 2018), what is lacking is inquiry addressing this type of disclosure from teachers. As Dr. Joshua Gordon, director of the National Institute of Mental Health, aptly articulated:

There is power in numbers. Mental illnesses affect tens of millions of people in the United States and across the globe each year. Each of these individuals has a singular, compelling story that conveys an understanding of the depth of suffering. (National Institute of Mental Health, 2018, para. 2)

There are currently thousands of teachers living with a mental illness, and they are in an ideal position, with their firsthand experience, to start the next wave of this discourse. However, before beginning this conversation, it is crucial to understand the potential risks that these disclosures may have on students' perceptions of teachers and the resulting classroom outcomes.

This study uses the lens of Communication Privacy Management theory (CPM) to analyze the impact an instructor's depth of disclosure of their mental illness can have on mental illness percpetions, classroom climate, teacher credibility, homophily, and social attraction. Past studies on these variables have largely failed to examine disclosures of a mental illness from teachers' perspectives, and, since these variables are often investigated within the realm of instructional communication research, it is necessary to understand their role amid this discussion. Discussing and disclosing one's mental health state lies at the very heart of authentic, 
productive student-teacher communication. The current study aims to address this lack of research and to uncover students' perceptions of teachers who employ this vulnerable type of disclosure. Further, studies have shown that students who choose to conceal their mental health issues tended to not receive the help and resources they need, eventually experiencing a negative shift in their academic status (Meluch \& Starcher, 2020). Should these students' teachers choose to disclose their mental health issues within the classroom setting, a new hope may emerge for these students who have fallen silent over the years because of these role models' disclosure. Moreover, this research explores possible avenues through which tangible action can be taken to continue combatting, and ideally end, the overall stigmatization toward those living with mental illness.

As of 2018, 47.6 million U.S. adults live with some form of mental illness (Substance Abuse and Mental Health Services Administration, 2019). Scholars and activists from multiple fields have recently focused their attention on mental health and mental illness, opening opportunities for a richer understanding of these topics (Berry et al., 2017; Chakravorti, Law, Gemmel, \& Raicu, 2018; Perry \& Pescosolido, 2015; U.S. Department of Health \& Human Services, 2019a). For the purposes of this study, it is important to define both mental health and mental illness. Smith and Applegate (2018) make the distinction between the two terms, emphasizing that the terms' definitions can overlap, but they should operate as separate entities. Mental health can be seen as an overarching category that is able include mental illness, and a person's mental health is often affected by the state of their mental illness; but, they are still separate concepts. This study operationalizes mental health as the culmination of our emotional, psychological, and social well-being (U.S. Department of Health \& Human Services, 2019b), which is "the result of personal characteristics (e.g., the ability to manage emotions) as well as 
biological, pharmaceutical, social, economic, and environmental factors" (Smith \& Applegate, 2018, p. 383). Additionally, this study coincides with the Fifth Edition of the Diagnostic and Statistical Manual of Mental Disorders' (DSM-V) definition for mental illnesses or disorders. Henceforth, this study will refer to the following definition when discussing mental illnesses or disorders: "a behavioral or psychological syndrome or pattern that occurs in an individual," where the consequences of such illness include "clinically significant distress (e.g., a painful symptom) or disability (i.e., impairment in one or more important areas of functioning)" (Stein et al., 2010, p. 9).

Many of these discussions are occurring in classrooms across the country, suggesting the importance of such teacher-student conversations (Barile, n.d.; Meluch \& Starcher, 2020; U.S. Department of Health \& Human Services, 2019a; University of Michigan Depression Center, 2019). Considering that educational institutions employ the greatest number of people over the age of 55 when compared to other professions in the general labor force, a generation of teachers will be retiring soon (Bureau of Census for the Bureau of Labor Statistics, 2018). A new wave of mental health-literate individuals will soon be taking these retirees' places in education, making it imperative that scholars explore how a new generation of teachers can change the educational landscape with their mental illness experiences.

\section{Mental Health and Mental Illness}

Approximately one out of every five adults in the United States currently has some form of mental illness (National Institute of Mental Health, 2019). Communication scholars have recently begun nationwide conversations to reduce the stigma associated with mental health and mental illness (Hall \& Miller-Ott, 2020; Kreps, 2020; Meluch \& Starcher, 2020). Research has addressed various subject areas directly tied to mental health issues; some foci include analyses 
of healthcare systems (Flood-Grady, Kellas, \& Chernin, 2020; Hagmajer \& Strekalova, 2020; Kreps, 2020), family communication (Craig \& Moore 2020; Curran \& Scharp; 2020; SmithFrigerio, 2020), media portrayals (Hoffner, 2020; McLemore, 2020), the military (Samp \& Cohen, 2020), romantic relationships (Delaney \& Basinger, 2020), marginalized groups and advocacy (Ball \& Strekalova, 2020; Kreps, 2020; Piercy \& Zanin, 2020), as well as the college classroom (Meluch \& Starcher, 2020). Still, many have argued that this knowledge needs to be significantly expanded (Goldman, 2018; Hall \& Miller-Ott, 2020; Rudick \& Dannels, 2018; Simonds \& Hooker, 2018; Smith \& Applegate, 2018). Furthermore, discourses regarding both mental health and mental illnesses have addressed the denigrating stigmatization that surrounds these issues.

\section{Stigmatizations of Mental Illness}

As Kreps (2020) posited, "social stigma is a primary factor inhibiting discussion about mental health concerns" (pp. 14). Academics have attempted to define stigmatization, or stigma, within mental health and illness discourse (e.g., Hatzenbuehler, Phelan, \& Link, 2013; Smith, 2007; Smith \& Applegate, 2018). For the purposes of this study, mental illness-related stigma will be operationalized as "the co-occurrence of labeling, stereotyping, separation, status loss, and discrimination" against those with a mental illness (Hatzenbuehler et al., 2013, p. 813). This stigma can manifest both externally (or through public means) and internally, as the effects of stigma often negatively affect a mentally ill individual's sense of self and identity (Rüsch, Angermeyer, \& Corrigan, 2005). Adverse effects also occur when mentally ill people are stigmatized, including a reluctance to seek help or treatment, a lack of understanding from others, fewer opportunities for professional and social activities, bullying, physical violence, and harassment (Mayo Clinic Staff, 2017). As Smith and Applegate (2018) aptly summarized, mental 
illnesses come with heavy baggage, since those with a mental illness must cope with greater rates of disability and death than those who are neurotypical. They further noted that individuals with low-to-moderate, positive senses of mental health, regardless of having a mental illness, tended to "have worse physical health outcomes, health care utilization, missed days of work, and psychosocial functioning” (Smith \& Applegate, 2018, p. 387). Scholars have inferred that stigmas are what foster these negative outcomes and create barriers for those with a mental illness, depleting "instrumental, social, and economic resources" for those struggling (Smith \& Applegate, 2018, p. 382). For example, K-12 students reported that it was this stigma that prevented them from accessing mental health services at their school (Bowers, Manion, Papadopoulos, \& Gauvreau, 2013).

\section{Combatting the Stigma}

Scholars have highlighted various efforts that debunk, prevent, and eradicate these stigmas surrounding mental illnesses (Corrigan et al., 2012; Corrigan et al. 2016; Eisenberg, Downs, Golberstein, \& Zivin, 2009; Goldman, 2018). Since stigma “often leads to stereotyping and limit[s] knowledge about the best ways to interact with and help persons with mental health problems" (Kreps, 2020, pp. 16), previous efforts focused on correcting inaccurate labels about mental illness and providing realistic, factual information (Corrigan et al., 2012). For example, Rüsch et al. (2005) offered specific strategies for combatting deeply rooted, negative stigmas, underlining forms of education, protest, and direct contact as best practices. Yet, Smith and Applegate (2018) attested that educational settings are primed "to create new stigmas, bolster existing ones, or help eliminate them or reduce their power" (p. 383). Although, they argued that the most effective way to end these stigmas is through in-person interventions, clarifying that these "contact interventions are not simply about spending time with others (e.g., inclusive 
classrooms or mainstreaming in K12 settings) but about interventions in which someone discloses their experiences of living with mental health issues" (p. 389). However, while these interventions foster mental health and illness literacy within the physical classroom itself, they fail to address instances of combatting stigma prior to entering or simply outside of the classroom (e.g., in out-of-class communication, course documents, etc.).

While efforts clearly have been underway to mitigate existing stigmas, the National Alliance on Mental Health (2012) reported that $64 \%$ of student drop-outs blamed their mental illness for their departure. This statistic, although dated, emphasizes a need to initiate these conversations with students in an attempt to foster understanding instead of frustration with all involved parties. Stigmatization can be reduced in the classroom setting, and, with positive outcomes reported from mental illness discourse, it is clearly an influential and effective place to have these conversations (Šouláková, Kasal, Butzer, \& Winkler, 2019). For instance, Doll, Nastasi, Cornell, and Song (2017) stressed a number of effective practices for addressing mental health in school-based settings, with some benefits including better access to mental health and accommodation services, promoting universal comfortability, and reducing current stigmatizations. Thus, classroom settings, both in and out of the actual classroom, are uniquely positioned to prime both teachers and students to discuss mental health and mental illness comfortably and productively.

\section{Disclosure in the Classroom}

Students' mental health should be a growing concern for educators and advocates (Goldman, 2018; Simonds \& Hooker, 2018). Classrooms in higher education offer a unique setting in which to understand mental health and mental illness, while simultaneously offering a safe space for individuals to potentially disclose their own issues with mental health and mental 
illness. In terms of student disclosure, research has indicated that white individuals generally disclose more than from those who are not white, likely due to the higher stigma that is prevalent in communities of color (Abdullah \& Brown, 2011; Kreps, 2020). Thus, much of the existing research is likely skewed to be more representative of white individuals' experiences. Research on mental illness disclosure in the classroom setting specifically has discussed student disclosure at length (Brown et al., 2018; Corrigan et al., 2016; Eisenberg et al., 2009; Eisenberg, Hunt, \& Speer, 2013; Kranke, Jackson, Taylor, Anderson-Fye, \& Floersch, 2013; Wood et al., 2014). Reports indicated that only $50 \%$ of college students disclosed their mental health condition to their teachers, suggesting that half of this population is suffering in silence (The National Alliance on Mental Health, 2012). This reluctance to disclose could be explained in part by Moses' (2010) study, in which they found that adolescents who disclosed their mental health issues experienced stigmatization from some of their peers, teachers, and school staff.

Considering that roughly one-in-four U.S. students claimed that their mental health issues have interfered in the classroom, there is a need to analyze and intervene in the classroom with mental health and mental illness-related situations to help students who are struggling (Roeser \& Eccles, 2014). One way to study this disclosure is with a foundational understanding of Communication Privacy Management (CPM).

\section{Communication Privacy Management Theory}

CPM was initially positioned by Petronio (2002) as a dialectical theory in which "people make choices about revealing or concealing based on criteria and conditions they perceive as salient, and that individuals fundamentally believe they have a right to own and regulate access to their private information" (pp. 2). CPM revolved around the concept of disclosure and whether an individual should choose to do so in various contexts. Petronio made a point to distinguish 
self-disclosure from private disclosure, where self-disclosure originally focused on the individual who was disclosing. Private disclosures, and, eventually CPM in general, looked comprehensively at the contextual levels involved and took into account how all individuals are affected by the disclosed information. However, private disclosure can still involve analyzing self-disclosure, just more holistically. CPM was traditionally approached with a three-prong framework through which privacy rules were implemented. This process included a contextual development of privacy rules, creating personal and collective boundaries for private information, and preparing for potential, and likely, violations of these boundaries (Petronio, 2002).

Petronio (2013) recently provided an update with advancements to the overall theory, noting, "CPM theory continues to depend on a privacy boundary structure to illustrate where private information resides as well as the way information is regulated and adheres to a dialectical framework" (p. 8). She highlights three primary elements that collaborate to create the overarching system that is CPM. First, she addresses privacy ownership, which is where privacy boundaries are defined, thus making information private. Petronio furthers that this ownership subsequently can either be restricted or shared with others, emphasizing the relational aspects of CPM. The second element in the CPM process is identified as privacy control, which is said to symbolize "the engine that regulates conditions of granting and denying access to private information" (Petronio, 2013, p. 9). Lastly, Petronio describes privacy turbulence, wherein privacy regulation can be disrupted or completely break down. All three of these elements contribute to the process of managing one's privacy in varying degrees and contribute to scholarly understandings of related behaviors and decisions. 
Petronio (2013) also elaborates on eight axioms that are involved in CPM, all emphasizing "predictions for the way people enact their management of private information" (p. 8). While these axioms are not particularly necessary for the purposes of this study, as it focuses more on outside perceptions of disclosure rather than ways individuals manage disclosure themselves, Axiom \#7 of CPM reminds that "collective privacy boundaries are regulated through decisions about who else may become privy, how much others inside and outside the collective boundary may know, and rights to disclose the information," again emphasizing the relational importance of CPM (Petronio, 2013, p. 11).

While there are benefits to disclosing one's private information, such as stronger relations among individuals, Petronio (2002) also claimed that there are many risks involved with this act. She identified what she deemed as "role risks," or risks "that have the potential to jeopardize our standing if we disclose private information" (Petronio, 2002, pp. 71). Depending on the standing of the discloser, disclosure could potentially affect either the student's or teacher's reputation. Risks of stigmatization are an additional factor to consider when disclosing private information because one may hold back from disclosing if they fear being discredited or dismissed.

CPM has been used in a variety of research contexts over the years, including studies of CPM's roles in the workplace (Helens-Hart, 2017) and social networking (Imlawi \& Gregg, 2014). Of note, the classroom provided a useful context for CPM to be heavily analyzed. Multiple studies using CPM have analyzed students' navigations of various disclosure in the classroom (Henningsen, Valde, Entzminger, Dick, \& Wilcher, 2019; Johnsen, Robinson, \& Luckasen, 2017; Nodulman, 2011; Price, Carmack, \& Kuang, 2020; Wright, 2013). On the other side of the classroom, teachers' disclosures specifically within the classroom have also been of interest to researchers (Goodboy, Carton, Goldman, Gozanski, Tyler, \& Johnson, 2014; Hosek 
\& Thompson, 2009; Kaufmann \& Lane, 2014; McKenna-Buchanan, Munz, \& Rudnick, 2015;

Schrodt, 2013). In particular, Song, Kim, and Park's (2019) findings noted that a teacher's social presence mediated a teacher's self-disclosure and the teacher-student relationship, prompting further investigation on the impacts that specific types of instructors' self-disclosure can have on this vital classroom relationship.

\section{Instructor Self-Disclosure}

Meluch and Starcher (2020) remind that "instructors struggling with a stigmatized mental illness, such as a depression, may feel the need to effectively manage their private information regarding their illness in order to be seen as credible among students in the classroom setting" (pp. 151). However, McBride and Wahl (2005) claimed that the best teachers have used "narratives and self-disclosures when it was relevant to course content" to advance the class (p. 15). Thus, many teachers have attempted to use disclosure in the classroom, as students tended to appreciate instructors' self-disclosure as a way of getting to personally know them (Martin, Myers, \& Mottet, 1999).

Studies regarding instructor self-disclosure have largely concentrated on ways to appropriately and efficiently disclose in classroom settings (Cayanus, 2004; Cayanus \& Martin, 2008; Hosek \& Presley, 2018; Hosek \& Thompson, 2009; Kaufmann, 2011; McBride \& Wahl, 2005; McKenna-Buchanan et al., 2015; Minger, 2004; Sorensen, 1989; Wiedenhoeft, 2007). Investigations of teachers' self-disclosure to their students have resulted in studies ranging from women of color's disclosure of their age (Smith-Tran, 2019) to alcohol-use disclosure (Brophy, 2018). Studies in this field have also analyzed the disclosure of instructors' nonheteronormative sexual orientations (Allen, 1995; Boren \& McPherson, 2018; Bower-Phipps, 2017; Coker \& Cain, 2018; Corrigan \& Matthews, 2003; Cramer, 1997; Liddle, 1997; McKenna-Buchanan et 
al., 2015; Orlov \& Allen, 2014; Rudnick, 2012; Russ, Simonds, \& Hunt, 2002; Wells, 2017);

notably, many of these studies emphasize the importance of cultivating classrooms in which an instructor has the ability to disclose something as personal as their sexual orientation in order to help both students and themselves. This is especially significant as non-neurologically normative disclosures are comparable in this instance and pose similar risks.

Analyses of instructors' disclosures in the classroom have historically had mixed results, as some of the following studies indicate. Sidelinger, Nyeste, Madlock, Pollak, and Wilkinson (2015) investigated instructors' general self-disclosure in order to see if it had a positive or negative impact on students. Overall, they found that inappropriateness and excessive disclosure made students less satisfied with their instructors' communication (Sidelinger et al., 2015). Borzea and Goodboy (2016) found similar results regarding perceived instructor misbehaviors through their disclosure. Alternatively, Lannutti and Strauman (2006) conducted a study on teacher self-disclosure, finding that intentionality, honesty, and positivity produced more positive assessments of the instructor, suggesting optimistic outcomes when instructors disclose. Cayanus and Martin (2008) found heightened student-experiences in the classroom when a teacher's selfdisclosure had significant relevancy and valency. Similarly, Schrodt (2013) deduced that elevated perceptions of instructor self-disclosure were directly related to student comfortability, content relevance, and disclosure appropriateness. Mazer, Murphy, and Simonds (2009) also conducted research investigating the effects of teacher self-disclosure through computermediated communication (CMC); this study uncovered positive correlations among CMC disclosure and student motivation, affective learning, and classroom climate. In sum, instructors need to find a balance that simultaneously maintains their own privacy and creates a certain level of openness and immediacy with their students (McBride \& Wahl, 2005). This body of literature 
warrants an updated examination and clarification to see how students currently view teachers' use of self-disclosure, specifically in the realm of mental health.

\section{Instructor Disclosure of Mental Illness}

There is currently scant and varied research that investigates instructors' disclosure of a mental illness in the classroom and the role risks that may be associated with doing so. In 2018 alone, there were 1.5 million teachers with a mental illness who, to this day, have gone undernoticed and under-researched (American Psychiatric Association, 2018; Bureau of Census for the Bureau of Labor Statistics, 2018). Moreover, 58\% of educators have also stated that their general mental health was in a poor state (Toppo, 2017). Not only do those who live with these mental illnesses have to overcome the barriers put in place by their condition, but they also must combat misconceptions that society places on their illness. Additionally, mentally ill instructors must deal with the cumbersome weight of maintaining their stature inside and out of the classroom to avoid role risks. Since Smith and Applegate (2018) argued that "communication is implicitly needed to achieve [good] mental health," those who need to talk about their problems should aim to do so in order to promote their mental well-being (p. 389).

There are a number of instructors who have taken this step, with little research that analyzes the impact of their disclosure. The research that does exist explored how mentally ill college and university faculty were able to disclose some of their struggles. This research tended to target graduate students' experiences, as well as faculty-based perceptions of the benefits and costs of disclosing mental health issues (Levecque, Anseel, Beukelaer, Van der Heyden, \& Gisle, 2017; Meluch \& Starcher, 2020; Price \& Kerschbaum, 2017; Reevy \& Deason, 2014). Price, Salzer, O'Shea, and Kerschbaum (2017) found that, among the $20 \%$ of participants that willingly disclosed to their students, there were more positive outcomes than neutral or negative ones; 
although, the results of this study are limited, as they did not analyze the disclosures' direct impacts and are a result of naïve quantification that lacks a clearly identified methodology. This vague, exploratory nature warrants more targeted, empirical analyses. In addition, Renuka Uthappa (2018) delved into a hypothetical, auto-ethnographical self-analysis, in which she discussed the positive possibilities that could come from disclosing her mental disability to her students (e.g., helping to end its stigma) and offered a lesson plan for how she should have gone about disclosing to her students. In another auto-ethnographical approach, Campbell (2018) broke down her own disclosure of mental illness in the classroom, insinuating that such disclosure was a valuable tool for classroom educators that should be more widely implemented. On the other hand, White (2007) directly analyzed the positive and negative potentials of an instructor disclosing their mental illness, finding that these individuals did fear disclosing, but also wished to disclose in spite of their fears and existing stigma. White emphasized that this disclosure often "makes it easier for [students] to understand that the mentally ill are all around us, that we are not to be feared, that treatment can work, and that career and success in life are indeed possible" (White, 2007, p. 141). While these findings help to expand the knowledge regarding instructors' disclosure of mental illness, they are quite limited in scope being that they solely focus on the field of social work.

One recent publication that mirrored aspects of this study concerned instructor disclosure of communication apprehension in the classroom. Meluch, Feehan, and Starcher (2019) investigated how students' perceptions of an instructor's credibility were affected in the public speaking classroom after their instructor disclosed that they were communicatively apprehensive. The study also explored how this disclosure was beneficial to students who were experiencing similar public speaking-related nervousness. For reference, communication apprehension refers 
to a person's level of fear or anxiety from either real or anticipated communication with another person (McCroskey, 1977). Meluch et al. (2019) indicated that teachers who disclosed their communication apprehension were viewed as more competent by their students, as this made them see their instructors as a vital resource to help students overcome their own public speaking fears. Communication apprehension has close ties to mental health and mental illness, and "to better address mental health in public speaking courses, it is important to conceptually understand the overlaps and distinctions" among public speaking anxiety, social anxiety disorder, and generalized anxiety disorder (Simonds and Hooker, 2018, p. 395). As Bodie (2010) articulated, public speaking anxiety is a particular type of anxiety that is both part of, and distinct from, communication apprehension that is addressed in public speaking courses. He clarified that public speaking anxiety is a specific type of communication-based anxiety wherein individuals can experience "physiological arousal," "negative self-focused cognitions," and "behavioral concomitants," all in response to a presentation (Bodie, 2010, p. 71). The similarities of these concepts and the current study's variables could suggest comparable outcomes for similar situations of disclosure in the classroom setting. As the limited, previously highlighted research also indicates, direct effects of instructors' disclosure of mental illness warrants more attention.

Notably, Meluch and Starcher (2020) attempted to bridge this gap in research by specifically analyzing how an instructor's disclosure of their depression in the classroom can directly affect their credibility as a teacher. Utilizing hypothetical behavior-based scenarios, differentiated by disclosure and gender, and open-ended questions, the study also investigated how, if at all, this type of disclosure could benefit the students that heard it. The qualitative results of the study found that students tended to view their instructors who disclosed their depressive state "as more understanding and able to relate more to student experiences," thus 
reducing stigmatization and supporting students who also had mental health issues (pp. 158). However, the quantitative data suggests that this type of instructor self-disclosure actually lessens their credibility as a teacher, indicating that some students still want some privacy boundaries in place with their teachers. This study seeks to clarify and further investigate some of Meluch and Starcher's results, as their findings were sometimes contradictory; the same can also be said for all of the aforementioned studies, as the results varied. Along with an analysis of these classroom-specific disclosures, an investigation on the environment itself is warranted to understand the full contextual impact of these disclosures.

\section{Classroom Climate}

One classroom-centric concept that is often investigated in teacher-student environments and interactions is the classroom climate, which has been studied for years in the communication and educational fields (Fraser, 1994, 1998, 1999, 2012). As Fraser (1998) noted, "few fields in education can boast the existence of such a rich array of validated and robust instruments which have been used in so many research applications" (p. 8). In essence, a classroom's climate (or learning environment), is the "characteristics of the environment inside the classroom that are perceived” (López et al., 2018, p. 408). Rowe, Kim, Baker, Kamphaus, and Horne (2010) summarized that this research has typically investigated variables often occurring within the classroom's climate, such as student motivation, engagement, and achievement. Fraser (1999) also found that classroom climate heavily influenced students' achievements in the classroom, affecting coherence, goals, and organization. In short, classroom climate has a significant influence on students' well-being and success in the classroom and warrants further research. While some of the previously mentioned studies address the positive affects instructor disclosure has had on a classroom (e.g., Mazer et al., 2009), no contextualized research currently exists that 
addresses the impacts an instructor's disclosure of mental illness can have on a classroom's climate.

\section{First Day of Class}

A principal element to establishing a positive classroom climate is the first day of class.

For both teachers and students, this day provides integral introductions to many of the anticipations and opportunities expected from the classroom setting (Curtis \& Moore, 2018;

Gross Davis, 2009; Robinson, 2019). Hayward (2003) implied that teachers have much of the control when it comes to establishing and implementing expectations on this first day. It is surmised that these earlier interactions with teachers often influence students' expectations and the class' tone for the entirety of the course (Henslee, Burgess, \& Buskist, 2006; Horan, Houser, Goodboy, \& Frymier, 2011). Instructors often utilize this time to set the ground rules for their classroom and discuss the specifics for their class standards. However, Goldman (2018) argued that this is a pivotal moment in which teachers can, and should, discuss other considerations that may influence their students' experiences in the classroom, such as their mental health.

\section{The Syllabus}

Along with the first day of class, the syllabus plays a crucial role in establishing classroom expectations and norms in a more concrete form. Palmer, Wheeler, and Aneece (2016) roughly defined the syllabus as the following:

The syllabus is a physical artifact outlining key structural elements of a course. It often serves contractual, record keeping, and/or communication functions. It is the place where faculty describe what content they will cover, what books and articles their students will read, the assignments they will complete, dates when things are due, and all the policies and rules that are supposed to keep everyone happy and out of trouble. (p. 37) 
Instructors have attempted to address the role of the syllabus over the years, only to find mixed conclusions for how to approach one (Jabbar \& Hussain, 2017; Jenkins, Bugeja, \& Barber, 2014; Leeds, 1992; Palmer et al., 2016; Parkes \& Harris, 2002). Leeds (1992) attested that it is through the syllabus, and in the classroom, that students sought to discover what their instructor's expectations are, being that "the more knowledge the students possess concerning the relationship between themselves and the instructor, the more relaxed and comfortable they will be" in the class (p. 4). Jenkins et al. (2014) noted that course syllabi act as a source from which limited information is obtained by students to form impressions about the instructor. Parkes and Harris (2002) added that the syllabus displays the instructor's attitude toward the class and its subject matter, giving students the opportunity to use this document as a guide for the class and, potentially, the instructor, as well. Furthermore, the document holds a significant, foundational influence on classroom expectations and impressions, suggesting it may be a chief vessel in establishing acceptance and productive discourse about mental health and mental illness. Parkes and Harris also noted that a syllabus ideally should aim to mention the certain rights, responsibilities, and available accommodations for students with disabilities. With all of these safeguards in place for students with disabilities, it seems fitting for instructors to use the syllabus in a similar fashion to address their past and present mental health situations. As there are currently too few studies that investigate a teacher's disclosure of any matter within the syllabus, the importance of the syllabus suggests further investigation into its usage with the subjects of disclosure and mental health. Moreover, the question also remains if disclosing a mental illness will pose a risk to instructor credibility. 


\section{Instructor Credibility}

Since Myers (2001) argued that teacher credibility is vital for students to learn

effectively, an analysis of an instructor's credibility in the classroom is warranted with this topic.

Credibility has been defined as one's attitude toward the image held by a communicator at a given time (Andersen \& Clevenger, 1963; McCroskey \& Young, 1981). Perceived instructor credibility is vital to both instructors and their students, as these situations have garnered higher learning, satisfaction, and evaluations (Obermiller, Ruppert, \& Atwood, 2012). Furthermore, teacher credibility has often been studied in tandem with other aspects of the classroom, like teacher immediacy (Gilchrist-Petty, 2017; Mazer \& Stowe, 2016; Teven \& Hanson, 2004;

Thweatt \& McCroskey, 1998) and affective learning (Banfield, Richmond, \& McCroskey, 2006; de Boer \& Bordoloi, 2018; Fisher Clune, 2009; Ledbetter \& Finn, 2018; Teven, 2007). While many of these studies explored how teachers establish their credibility, few have examined how teacher credibility may be compromised using CPM, specifically examining the role risks of certain disclosures (e.g., the disclosure of mental illness).

Teacher credibility is often rooted in Aristotle's discussion of ethos, which is comprised of a person's intelligence, character, and goodwill (Teven \& McCroskey, 1997). The concept of goodwill was later adapted to be more focused on a person's perceived level of caring about an individual and then further broken down into three sublevels that encapsulate the ways in which a person can achieve credibility: empathy, understanding, and responsiveness (Teven \& McCroskey, 1997). McCroskey and Young (1981) added that credibility could also be comprised of competence, character, sociability, extroversion, and composure.

Few studies have investigated the impacts that teacher self-disclosure may have on their credibility with students. The aforementioned study by Mazer et al. (2009), regarding instructor 
self-disclosure through $\mathrm{CMC}$, found "that when a teacher self-discloses certain information, such as personal pictures, messages from friends and family, and opinions on certain topics, students might perceive similarities between themselves and the instructor" (p. 180). The study also revealed a positive correlation between a teacher's self-disclosure and credibility, paving a road for future research to further investigate the relationship between instructors' self-disclosure and teacher credibility (Mazer et al., 2009). Wang, Novak, Scofield-Snow, Traylor, and Zhou (2015) conducted a similar study in which the results were more varied. Specifically, they found a gendered bias in the disclosure's impact, where a male teacher's self-disclosure negatively impacted their credibility, but a female teacher's credibility was not affected (Wang et al., 2015).

Gilchrist-Petty (2017) reminded that "credibility is fluid, situationally dependent, and not automatically given," and many teachers are rightfully concerned about creating and preserving their credibility in the classroom (p. 49). Notably, a recent study found that instructors actually established their credibility through self-disclosure, but only when effectively disclosing information relevant to the students and the course's material (Myers, Brann, \& Members of Comm 600, 2009). These results give a hopeful outlook in this field, with students indicating that they want instructors to continue disclosing in future instances. Additional studies have also investigated the relationship between students' perceptions of teacher credibility and instructor disclosures with mixed results (Imlawi, Gregg, \& Karimi, 2015; Klebig, Goldonowicz, Mendes, Miller, \& Katt, 2016; Miller, Katt, Brown, \& Sivo, 2014). This suggests a need to investigate specific types of teacher self-disclosure and their impacts on a teacher's credibility, as it has become a prominent facet of the classroom experience, and variations in levels of disclosure can have significant impacts that are varied. Furthermore, with such a wide variation in existing 
analyses of credibility, more research is warranted to clarify whether certain disclosures may provide specific role risks for the instructor in this field.

\section{Instructor-Student Relationship}

In addition to establishing and maintaining their stature in the classroom, teachers must also form positive relationships with their students (Hosek \& Thompson, 2009). Scholars have attempted to articulate the nuances of the teacher-student relationship, generally concluding that it is vastly complex and constantly evolving (Docan-Morgan, 2011; Frymier \& Houser, 2000; Gilchrist-Petty, 2017). Gilchrist-Petty (2017) aptly identified many of the key variables integral to the teacher-student relationship, including credibility, race, and sex. Teven (2001) argued that teachers and students must develop positive relationships as these often determine the students' performance and levels of interest in the classroom. In light of these findings, the student-teacher relationship is one that demands further investigation. One facet of this relationship that has had a fair amount of exposure in academic studies is homophily.

\section{Homophily}

While there is an inherent power dynamic that exists in the teacher-student relationship, it is still possible for a unique level of closeness to emerge. Homophily is simply defined as “source-receiver similarity" (McCroskey, Richmond, \& Daly, 1975, p. 323). A more fleshed out definition described homophily as the idea that "contact between similar people occurs at a higher rate than among dissimilar people" (McPherson, Smith-Lovin, \& Cook, 2001, p. 416). Homophily often specifically investigates levels of attitude, morality, appearance, and background, as these variables tend to appropriately encapsulate how individuals can judge their similarities with another person (McCroskey et al., 1975). Much existing research highlighted the role homophily plays in classroom friendships, often addressing factors that tended to 
influence these friendships, like race and gender (Daw, Margolis, \& Verdery, 2015; Echols \& Graham, 2013; Jugert et al., 2017; Jugert, Leszczensky, \& Pink, 2018; Mamas, Daly, Struyve, Kaimi, \& Michail, 2019; McCormick, Cappella, Hughes \& Gallagher, 2015; Mollica, Gray, \& Treviño, 2003; Smirnov \& Thurner, 2017). Most of these studies have found that high levels of homophily indicated positive, strong relationships among individuals. Other variables have been investigated with homophily, specifically in relation to students' perceptions of their instructors, including humor (West \& Martin, 2019), teacher immediacy (Miller et al., 2014; Powell, Hamilton, Hickson III, \& Stuckey, 2001; Rocca \& McCroskey, 1999), and fashion choice (Gorham, Cohen, \& Morris, 1997; Morris, Gorham, Cohen, \& Huffman, 1996).

Rocca and McCroskey's (1999) study found that high teacher immediacy, a way in which to reduce relational distance between teachers and students, resulted in high levels of homophily and social attraction. It is suggested, then, that other ways of closing this relational gap could have similar results. And, with the sole homophily studies that investigated mental illness in the communication field regarding both CMC (Wright, 2000) and health communication (Quintero Johnson, Yilmaz, \& Najarian, 2017), an investigation into other communication fields is needed to further understand homophily's effects, especially since mental illness disclosure from instructors could lead to perceptions of greater homophily with students who have had similar struggles. Likewise, the same could be said for studies of social attraction.

\section{Social Attraction}

Social attraction falls under the category of interpersonal attraction, which has historically been used to examine various interpersonal, communicative instances, particularly as a cause and effect of communication (Berscheid \& Hatfield Walster, 1969). The three facets that have traditionally been studied in interpersonal attraction include task attraction, social 
attraction, and physical attraction (McCroskey \& McCain, 1974). Significantly, McCroskey and McCain concluded that interpersonal attraction, influence, and willingness to communicate were all positively correlated with one another. Furthermore, Weiss and Houser (2007) conducted one of the few studies that dove into the relationship among instructors, students, and interpersonal attraction. They ultimately found a positive connection among all three facets of interpersonal attraction (i.e., task, social, and physical) and students' desire to communicate for relational and participatory purposes. In applying this interpersonal framework to a classroom setting, one can conclude that students could be more influenced and willing to communicate with their teacher should they be attracted to the teacher under these standards. This influence could even extend to mental health and mental illness discussions in the classroom, with this willingness to communicate possibly creating a framework for more open communication regarding these issues. With so few current studies analyzing interpersonal attraction in the classroom and the evident, direct relationship between interpersonal attraction and mental illness, a further investigation into the impacts of this study's variables on teacher-student interpersonal attraction is warranted.

\section{Research Questions}

This study aims to explore instructor self-disclosure of mental illness to investigate the stigma surrounding mental illness. Being that this stigma has persisted for some time, it is expected to seep into the classroom setting, either from students or their instructors. Smith and Applegate (2018) argued that instructors who choose to disclose a mental illness intentionally raise the stakes for their role as a teacher, especially since "anticipating and experiencing these acts affect how people function in society as a whole and in education settings specifically" (p. 382). Further, Wood, Bolner, and Gathier's (2014) study regarding self-disclosure in the 
classroom posited that "educators must help facilitate the class discussion through the discomfort that may emerge from mental health self-disclosures" (p. 90). Numerous studies have already investigated some of the previously mentioned variables, such as teacher credibility, attractiveness, and homophily (Myers \& Huebner, 2011), as well as interpersonal attraction (Rocca \& McCroskey, 1999). But, further analysis is warranted to analyze how an instructor's disclosure of their mental illness through the syllabus could directly impact student perceptions of mental illness, the classroom climate, and the teacher's credibility, homophily, and social attraction. This study aims to analyze the effects this direct disclosure will have in the classroom and will address the following research questions:

$\mathrm{RQ}_{1}$ : Does an instructor's level of disclosure of mental illness in a class syllabus alter students' perceptions of mental illness?

$\mathrm{RQ}_{2}$ : Does an instructor's level of disclosure of mental illness in a class syllabus alter students' perceptions of their anticipated classroom climate?

$\mathrm{RQ}_{3}$ : Does an instructor's level of disclosure of mental illness in a class syllabus alter students' perceptions of credibility of their instructor?

$\mathrm{RQ}_{4}$ : Does an instructor's level of disclosure of mental illness in a class syllabus alter students' perceptions of homophily with their instructor?

RQ5: Does an instructor's level of disclosure of mental illness in a class syllabus alter students' perceptions of social attraction to their instructor? 


\section{CHAPTER II: METHODS}

\section{Participants}

Students from a large Midwestern university served as participants in the study after giving Institutional Review Board-approved consent. Participants had to include at least 44 college-aged students per group in order to uphold a power level of 0.80 to detect an effect of medium size at $p=0.05$ (Keppel, 1991). There were 148 participants over the age of 18 in total that participated in this study. Individuals from a pool of participatory volunteers were used as a convenience sample. Of these participants, $75.5 \%$ identified as women, $23.1 \%$ identified as men, and $1.4 \%$ identified as genderqueer/nonbinary. Respondents between the ages of 18 and 23 made up $55.9 \%$ of the study's responses, while $5.1 \%$ was made up of those aged $24-28,2.5 \%$ was made up of those aged 31-39, and the rest of the participants were between 41 and 59 years old. Additionally, $75.4 \%$ of participants were Caucasian/Non-Hispanic, 9.5\% were Hispanic, $6.8 \%$ were African American, and 4.1\% were Asian/Pacific Islander. Furthermore, $66.0 \%$ of participants reported to not have a diagnosed mental illness, while $34.0 \%$ of respondents said they did; $56.5 \%$ of respondents also reported that they had used a counseling service/therapy in the past, and the majority of them (73.5\%) reported their mental health at a 6 or higher on a scale of 1 (Poor) to 10 (Great) at the time they took the survey. Moreover, $74.8 \%$ of them reported to have a family member or friend with a diagnosed mental illness.

\section{Materials}

Scholars agree that conducting studies with hypothetical, scenario-based research has numerous benefits and is a useful strategy when it comes to various research studies (Fahey \& Randell, 1998; Mietzner \& Reger, 2005; Ramirez, Mukherjee, Vezzoli, \& Kramer, 2015). Therefore, this study utilized hypothetical scenarios with varying degrees of a teacher disclosing 
their mental illness embedded within a syllabus' course policies. With the evident weight the syllabus carries, especially in establishing initial impressions for teachers and their classes, teacher self-disclosure through this medium is an appropriate angle through which to approach this study. The syllabus content can also be indicative of how the instructor establishes the climate of mental health and illness disclosure in other parts of the course. Participants were randomly assigned to one of three blind groups (no disclosure, partial disclosure, and full disclosure; see Appendices A-C for stimuli), in which they read a stimulus syllabus and then responded to a series of scaled items, which are detailed in the study's Measures.

For consistency's sake, a standardized syllabus template for an entry-level communication course was used as a base for the stimuli, as it has had excessive exposure in a number of classrooms already. In order to ensure that the stimuli scenarios used were distinct enough from each other, a precautionary manipulation check was conducted prior to participants receiving any study materials. In this manipulation check, three independent variables (no disclosure, partial disclosure, and full disclosure) were tested to verify that participants would regard said variables as this researcher intended (see Appendices D-F). Participants were asked to read a short excerpt of an instructor's syllabus and then indicate how much the instructor had disclosed about their mental health in said passage from the three given choices. The manipulation check ultimately showed that respondents did not see a distinct-enough difference among the three stimuli. To remedy this, it was decided that the "Mental Health Resources" section be completely removed from the null stimulus in order to help avoid confusion for future participants; additional language was added to the full disclosure stimulus to help differentiate between the partial and full disclosure stimuli, as well. 


\section{Measures}

A survey containing demographic items (see Appendix G) and measures concerning mental illness perceptions, classroom climate, teacher credibility, homophily, and social attraction was distributed to participants via a Qualtrics survey. As "researchers generally agree that a coefficient alpha of . 70 or greater is sufficient for establishing the internal reliability of a measuring instrument," all of the scales used in this study have sufficient internal reliabilities (Keyton, 2011, pp. 112). Rationale for specific scale usage and reliability procedures are detailed in the rest of this section. Items within individual scales that were reverse-coded prior to the data's analysis are marked with asterisks in Appendices H-N.

To investigate how students' perceptions of mental illness were impacted by this type of disclosure, an 11-item, 10-point Likert scale analyzing facets of self-disclosure and mental illness was created for this study to gauge how much participants agreed or disagreed with certain statements on a scale from 1 to 10 (see Appendix H). This scale used various statements that largely focused on the stigmatization of mental illness and subsequent perceptions. For example, some statements from this scale included, "Teachers should be able to discuss mental illness issues in the classroom," "I appreciated learning about this instructor and their relation to mental illness," and "Seeing the disclosure of a mental illness in the syllabus will be beneficial to my success in the classroom." If participants indicate higher scores for the statements, then they would agree with said statements and, thus, would have a positive perception of mental illnesses and related topics; lower scores would show that participants have negative perceptions of mental illness and mental health. As the statements used terminology relating to opinions of mental illness and mental health in the classroom setting, this scale's face validity was high. The 
alpha reliability of this scale was also found to be .84 , indicating this to be a relatively reliable scale.

To measure classroom climate, an amalgamation of multiple scales was compiled. The first measurement of classroom climate, specifically targeting the teacher-student relationship through interactions, was adapted from López et al. (2018). Using an 8-item, 5-point, Likert-type scale, this scale's original Cronbach's alpha reliability was .79, showing “adequate internal consistency" (López et al., 2018, p. 415). Statements regarding how participants would feel in the hypothetical classroom setting were given (e.g., "I would feel good and comfortable in this class," and "In this class, students could help deciding good climate and discipline rules for the classroom."). Then, participants indicated what their level of agreement was with each statement, ranging from 1 (I completely agree) to 5 (I completely disagree) (see Appendix I). Higher scores from participants indicate notions of agreement and positivity toward the classroom's general environment, and the opposite can be said for those with lower scores. The alpha reliability for the scale in this particular study was .81 .

Additionally, Gokcora's (1989) investigation into the atmosphere of a classroom's climate was influential on the development of this study's classroom climate scale. Gokcora investigated multiple facets of classroom climate, specifically looking at international teaching assistants' classroom-related communication strategies, as well as culturally related perceptions of teachers and their teaching. In her original study, she analyzed the classroom climate's atmosphere with a 15-item, 4-point semantic differential scale to assess English undergraduates' opinions on the subject. Participants in this study were given a revised, 8-item questionnaire using a more widely ranged, 7-point semantic differential scale than the original to investigate the atmosphere within a classroom's climate (see Appendix J). Similar to previous scales, higher 
scores from participants are indicative of agreement and positivity toward the classroom's overall atmosphere, and the opposite is true for those with lower scores. Questions concerning students' comfort levels, classroom treatment, and more are included. While no alpha reliabilities or factor analyses were reported in the original study, the alpha reliability for this revised portion within classroom climate testing was .91.

Teacher credibility was measured using revised statements influenced by McCroskey and Teven's (1999) 18-item, 7-point semantic differential scale researching specific components that make up a person's credibility (i.e., competence, caring/goodwill, trustworthiness). Alpha reliabilities for these measures typically ranged between .80 and .94 . For this study, 18 statements regarding participants' opinions about a hypothetical teacher's credibility were posed, followed by a 7-point semantic differential scale of answers to choose from (see Appendix K). The statements posed have participants indicate whether this hypothetical teacher was considered intelligent or unintelligent, moral or immoral, and more. Participants with higher scores view these instructors as more credible than those with lower scores. When totaled for this study, the alpha reliability for teacher credibility was .95 .

Next, to analyze homophily, two Likert-type scales derived from McCroskey, L., McCroskey, and Richmond's (2006) work were used. Background homophily and attitude homophily are specifically analyzed with these scales, seeking out any correlations between participants' backgrounds and attitudes with a hypothetical instructor. Background homophily's alpha reliability for McCroskey et al.'s study was between .81 and .84 , and the reliability for their attitude homophily test was between .92 and .95 . Just as they did for former parts of this study, participants were given one set of statements to respond to for both of these subsections [12 statements regarding background homophily (see Appendix L) and 15 statements regarding 
attitude homophily (see Appendix M)]; they then indicated where their answers fell on a 5-point Likert scale, ranging from 1 (I completely disagree) to 5 (I completely agree). Examples of the statements about background homophily include, "This teacher's background is similar to mine," and "This teacher is from a social class similar to mine." Additionally, some examples of statements from the attitude homophily scale include, "This teacher thinks like me," "This person shares my values," and "This teacher is similar to me." Participants with higher scores would have feelings of similarity with this teacher's background and this teacher's attitudes, and those with lower scores would feel dissimilarly. Once adjusted for this study, the scale for background homophily had an alpha reliability of .84 and attitude homophily was at .90 .

Finally, social attraction was analyzed also using McCroskey et al. (2006). Similar to how aforementioned scales were approached, a 12-item, 5-point Likert scale was used to research social attraction with an original alpha reliability between .91 and .94. In this study, participants were given a set of 12 statements to respond to by designating where their answers fell on a 5-point Likert scale, ranging from 1 (I completely disagree) to 5 (I completely agree) (see Appendix N). Some examples of statements that participants would respond to include, "I think this teacher could be a friend of mine," "I would like to have a friendly chat with this teacher," and "This teacher would be pleasant to be with." Higher scores from participants would indicate stronger feelings of social attraction toward the teacher, and the opposite would be true for respondents with lower scores. Once adapted for this study, this scale's reliability was .90 .

\section{Procedures}

Institutional Review Board approval was sought and obtained. Subsequently, volunteers were recruited with a variety of methods, including postings on various online platforms (e.g., Facebook, Twitter, Qualtrics). After reading and agreeing to the informed consent form, 
participants randomly were assigned to read one of the three possible syllabi. Each of the syllabi emphasized different levels with a hypothetical instructor's self-disclosure of their mental health and mental illness-related issues (e.g., no disclosure, partial disclosure, and full disclosure). After reading their respective stimuli, participants answered questionnaires utilizing the previously mentioned measures. 


\section{CHAPTER III: RESULTS}

To address the research questions, the independent variable for this study was an instructor's level of self-disclosure of a mental illness, using three levels of disclosure (no disclosure, partial disclosure, and full disclosure). The dependent variables analyzed were perceptions of mental illness, classroom climate, teacher credibility, homophily, and social attraction. Due to the high correlation among dependent variables, an omnibus MANOVA was conducted.

As Box’s M Test was non-significant, Wilks' Lambda was chosen as the test statistic for this study. Wilks' Lambda signified that the level of disclosure, regardless of the type, did not have any main, significant effect on many of the dependent variables analyzed, $F(14,278)=$ $1.53, p=.101$. Despite the lack of overall effects, there was a statistically significant difference on mental illness perceptions, $F(2,145)=5.69, p=0.004$, partial $\eta^{2}=0.07$, with those in the partial disclosure condition $(M=73.65, S D=17.76)$ scoring higher than those in the "Full Disclosure" condition $(M=63.31, S D=13.69)$ and the "No Disclosure" condition $(M=70.46$, $\mathrm{SD}=15.73$ ). In short, this means that participants who experienced the syllabus with a partial amount of mental illness-related disclosure from the teacher reported greater acceptance toward mental illness than those who read both the syllabus with a greater amount of disclosure (i.e., the Full Disclosure stimulus) and the syllabus with no disclosure (i.e., the null stimulus). See Table 1 for descriptive statistics table.

In order to investigate whether there were correlations among the study's dependent variables, a Pearson's correlation was run on the dependent variables. However, it is important to note that these correlations do not hold much practical relevance within the context of this study, being that none of them have very high correlations or have very dependable relationships, per 
this study's standards. These standards and interpretations of Pearson's correlation coefficients were based off of Keyton's (2011) outlined approach. A positive, albeit low and small, correlation was found between Mental Illness Perceptions and Background Homophily, $r(159)=$ $.24, p<.01$, Mental Illness Perceptions and Classroom Climate (Teacher-Student Interactions), $r(159)=.31, p<.01$, as well as Mental Illness Perceptions and Social Attractions, $r(159)=.36, p$ $<.01$. Additionally, moderate, positive correlations were found to exist among numerous dependent variables. Mental Illness Perceptions had these substantial, positive correlations with Classroom Climate (Atmosphere), $r(159)=.47, p<.01$, Teacher Credibility, $r(159)=.49, p<$ .01 , and Attitude Homophily, $r(159)=.42, p<.01$. Classroom Climate (Teacher-Student) also had moderate, positive correlations with Classroom Climate (Atmosphere), $r(159)=.66, p<.01$, Teacher Credibility, $r(159)=.57, p<.01$, Background Homophily, $r(159)=.40, p<.01$, Attitude Homophily, $r(159)=.51, p<.01$, and Social Attraction, $r(159)=.53, p<.01$. Classroom Climate (Atmosphere) also had these same trends in its correlations with Background Homophily, $r(159)=.46, p<.01$, and Attitude Homophily, $r(159)=.62, p<.01$, as did Attitude Homophily with Social Attraction, $r(159)=.63, p<.01$. Teacher Credibility had moderate, positive correlations with Background Homophily, $r(159)=.41, p<.01$, Attitude Homophily, $r(159)=.59, p<.01$, and Social Attraction, $r(159)=.67, p<.01$, too. Lastly, instances of high correlations occurred among some of the scales, as well. Classroom Climate (Atmosphere) had a high, positive correlation with both Teacher Credibility, $r(159)=.89, p<.01$, and Social Attraction, $r(159)=.72, p<.01$. Additionally, Background Homophily also had a high positive correlation with Attitude Homophily, $r(159)=.71, p<.01$, and Social Attraction, $r(159)=.77, p$ $<.01$. See Table 2 for full list of bivariate correlations. 


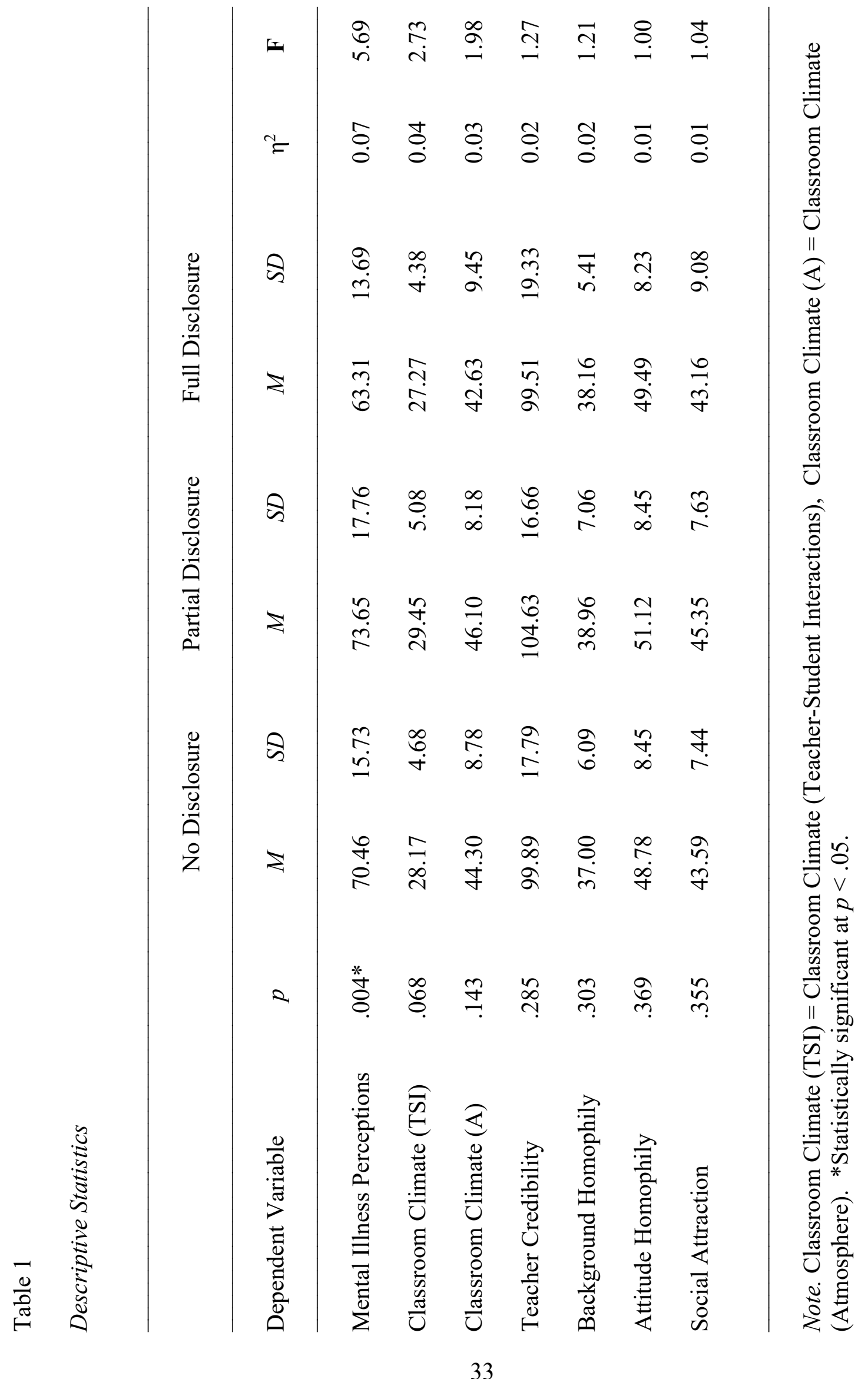




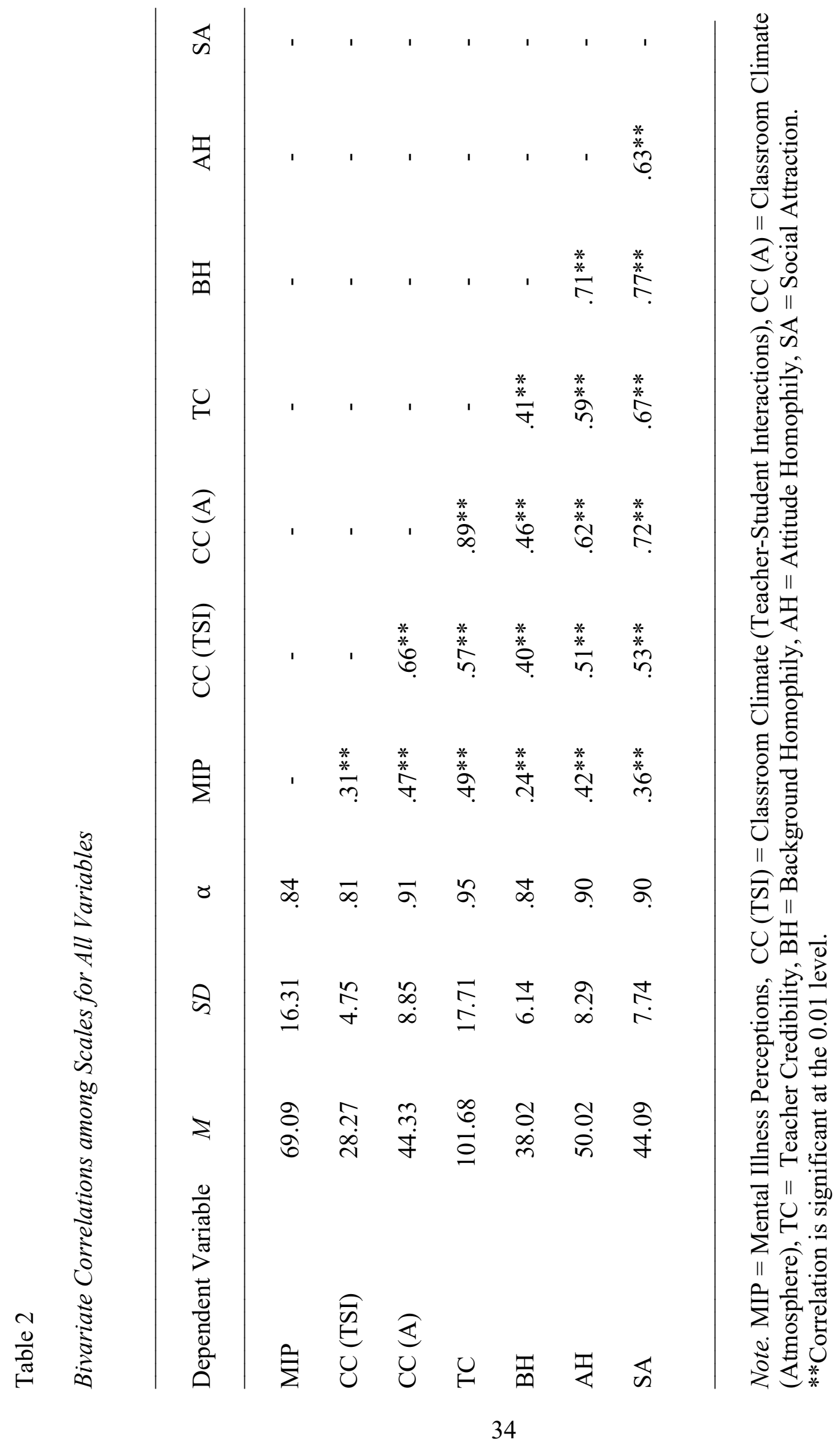




\section{CHAPTER IV: DISCUSSION}

\section{Summary of Findings}

This study aimed to investigate the impact of an instructor's depth of mental illnessrelated disclosure could have on student perceptions of mental illness perceptions, classroom climate, teacher credibility, homophily, and social attraction. According to the results of this study, collegiate teachers can disclose their mental illness to students through their syllabus without significant repercussions. This notion is exemplified by the single statistically significant difference found in the data regarding mental illness perceptions. Of the three randomly assigned stimuli, participants who engaged with the syllabus that only partially disclosed a mental illness indicated the highest level of support and agreement with progressive statements regarding mental health and mental illness when compared to participants in the other stimuli. When looking at the results holistically, it makes logical sense for the stimulus with only a partial amount of disclosure to be the most effective in instating positive perceptions of mental illness, as it stands to be the most well-balanced of the three in terms of its level of disclosure (i.e., Not too much disclosure, but also not too little.). Perhaps this form of self-disclosure was an effective way for students to get to personally know the instructor, as Martin, Myers, and Mottet (1999) argued. It is also possible that the Partial Disclosure syllabus effectively utilized concepts from Petronio's (2002) theory of CPM, especially since CPM's primary goal is to explain how and why people disclose or privatize information, by finding the appropriate balance between benefits and risks. This balance could be rationalized in tandem with other aforementioned sources, as well, including Cayanus and Martin (2008), Lannutti and Strauman (2006), and Schrodt (2013); all three of these studies partially credited intentionality and relevancy within 
teacher self-disclosures as rationale for its positive impact on students. It is probable that this study's results could also be due to its contextual situation.

Additionally, those who read the syllabus with the full-disclosure condition were the least supportive of these statements when compared to those in both the partial-disclosure condition and the no-disclosure condition. While the stimulus without any mental illness-related disclosure would obviously not rank highly with perceptions of mental illness, it is interesting that the stimulus with the heaviest form of disclosure garnered the lowest scores for Mental Illness Perceptions. This indicates that those who experienced more detailed, heavier versions of this disclosure viewed mental illness less highly than other participants. It is likely that those who viewed the Full Disclosure stimulus felt that they experienced a little too much disclosure from this instructor or that this disclosure was not as timely or as contextually relevant as it could have been. As Sidelinger et al. (2015) indicated, excessive disclosure tends to make students less satisfied with their instructors' communication, and this study appears to be no exception.

Although this disclosure is seemingly acceptable and uninfluential in multiple pedagogical realms, instructors should still be mindful of their level of mental illness-related disclosure, as too much can lessen the impact of destigmatization efforts in the classroom. Ultimately, and to answer the first research question, these results indicate that there is a need to have this type of disclosure in the classroom, as it significantly affected the way participants viewed mental illness and directly helped to lessen its stigma.

To address research questions two through five, the results of this study also revealed that there were no significant main effects with an instructor's mental illness disclosure and their classroom climate, teacher credibility, homophily, or social attraction. Ideally, one could hope to see significant results with any of the dependent variables, as this significance would have 
established an instance, or instances, of mental illness-related disclosure from teachers directly heightening their abilities in the classroom. However, this lack of significance is likely due to the deeply engrained stigmas that have been embedded throughout society for decades. Interestingly, Wood et al. (2014) makes the argument that "students who show indifference or discomfort may harbor stigma about people dealing with mental health problems," especially since their study's results indicated that students still held at least some uninformed beliefs and stigmas against mental illness (p. 90). This notion offers a completely different perspective regarding these results, as it suggests that the statistically insignificant results indicating participants' indifference toward classroom climate, teacher credibility, homophily, and social attraction should actually be considered bad results. But, if anything, it should reify the notion that indifference cannot be sufficient when it comes to mental health and mental illness awareness and advocacy. Wood et al. (2014) added that "student discomfort and irrational beliefs about mental health self-disclosers can highlight an opportunity to re-educate students about myths they have learned regarding mental health problems" (p. 90), which, at the very least, re-affirms the hopes and goals of this current study. Despite the numerous efforts that have been underway in both research capacities and practical contexts, these results do, however, still suggest that some of the world may be accepting of mental illness discourse and disclosure, but some may not be as openly inviting as one would hope.

Yet, these results do suggest that, should an instructor choose to disclose their mental illness via their syllabus, their classroom climate, teacher credibility, homophily, and social attraction would not be significantly affected. There is meaning in these technically insignificant results, given that there are no negative repercussions with any of the dependent variables from either type of disclosure. Moreover, these results should give solace to those instructors who are 
reluctant about disclosing something as personal as a mental illness, since, contextually, this disclosure does not negatively impact students' perceptions of them as a teacher. Perhaps those who have hidden their mental illness in the past will feel comfortable enough, and encouraged, to at least consider disclosing to their students via their syllabus in light of these results.

\section{Implications}

\section{Practical Implications}

Although some of these results are inconsistent with earlier research in similar contexts, this study provides useful updates and additional data to analyze in tandem with this pre-existing information. For example, since Myers et al. (2009) found that self-disclosure was productively and effectively used when information was relevant to the students and the course, it is possible that these results may be the product of the medium used for participants' stimuli. Likewise, Wood et al. (2014) argues, "if the disclosure is germane to the topics being discussed it has the potential for deepening respect, empathy, and understanding" (p. 90). Since the disclosure occurred within the "Mental Health Resources" section of the hypothetical syllabus, students likely viewed the disclosure as relevant within the context. The syllabus is also an ideal outlet through which to disclose this type of information, as aforementioned, and was likely influential on the findings of this study. Instructors should bear in mind the medium and context with which they disclose in light of these findings, as results may differ in varied situations of disclosure.

Additionally, future instructors should consider implementing this form of disclosure in their own classrooms for the benefit of their students. Wood et al. (2014) points out that hearing "self-disclosures of mental health concerns appears to have certain educational benefits" in the classroom, as students are able to integrate classroom content with real-world experiences via listening to the self-disclosures" (p. 90). College instructors' mental illness disclosures could also 
inspire opportunities for disclosure, resources, accommodations, and other positive outcomes for students, too. Already, a number of studies have discovered numerous benefits to providing healthy and productive classroom environments for the sake of students' mental health (Brown, S. L., 2002; Corrigan et al., 2016; Hartel, Nguyen, \& Guzik, 2017; Meluch \& Starcher, 2020; Miller, C. J., Borsatto, \& Al-Salom, 2019; Renuka Uthappa, 2018; Smith \& Applegate, 2018; White, M. A., Whittaker, Gores, \& Allswede, 2019; White, R., 2007). For example, Corrigan et al. (2016) found that college students who wanted to disclose their mental illness, in turn, wanted to join a program that aided them in making this disclosure. If college students' instructors take the first step with their own disclosure, this could provide students the safe environment, or program, that helps them feel more at ease to disclose with their peers, instructors, or both. Moreover, Kranke et al. (2013) established "that students make the decision to disclose to request accommodations" based on the "fear that their disability will greatly limit functioning critical to academic achievement," "the stability of their non-apparent disability," and the impact of students' self-stigma (p. 35). Potentially, teachers' mental illness disclosures could mitigate these fears and self-stigma, while simultaneously decreasing mental illness stigmatizations and creating another reason for students to feel comfortable in the classroom, especially concerning their mental health state.

\section{Theoretical Implications}

Finally, these results also inform CPM theory, particularly discussions regarding role risks. As these results are encouraging to teachers wanting to disclose their mental health experiences to students, Petronio's (2002) concept of a role risk is thus complicated. In CPM, Petronio originally claimed that certain private disclosures might be considered a risk to certain individuals' roles in society, particularly teachers, as these disclosures can purportedly 
jeopardize one's reputation. However, this study's results are indicative of a shift in this mindset, as the findings revealed no major risks to the hypothetical teacher's partial disclosure via the syllabus. While Petronio's notion of role risks in the realm of CPM still holds up with the results from the full disclosure group, her theory does not comply with the results from the partial disclosure group, wherein a private disclosure had no impact, positively or negatively, on the hypothetical teacher's role in the classroom. Yet, as Axiom \#7 of CPM clarified, these types of collective privacy boundaries are regulated by various relational factors. It appears the studentteacher relationship has evolved, as has CPM once again. While Petronio (2013) did provide an update to CPM's theoretical framework, given recent advancements in teacher-student relationship understandings and innumerous instances of research in similar fields, it seems that CPM is still in need of more improvements, especially in the realm of teacher-student relationships.

Furthermore, this study also intersects with some of the recent research regarding instructors' self-disclosure. Meluch et al.'s (2019) research indicated that teachers who had disclosed their communication apprehension were seen by their students as more competent, and Meluch and Starcher's (2020) study showed that students viewed instructors who disclosed their depression as more relatable and understanding. In similar fashion, this study further validates the positive impacts that can occur when instructors' mental illnesses are disclosed in the classroom. However, Meluch and Starcher's (2020) study also reported that this specific disclosure lessened their credibility as a teacher, which was not the case with this study. As this is still a newer field of research, developments are likely to continue unfolding. Ideally, these developments will eventually be able to identify and remedy the gaps that separate this study's findings from others mentioned. 


\section{Limitations}

\section{Limits to the Medium}

However, this disclosure, specifically via the syllabus, could be seen as a limitation of this particular study, especially since utilizing this medium excluded various in-person factors that are influential in a classroom environment. Although, Wood et al. (2014) makes the argument that "certain students may feel uncomfortable when hearing mental health disclosures regardless of the context in which it is shared" (p. 90). This could potentially justify another limitation of this study being its focus on the medium (i.e., the syllabus). With this in mind though, one could also argue that the data are not a result of the syllabus, but, rather, are a direct result of the participants' opinions about mental health and mental illness. This method was also limiting since these results are only indicative of a student's initial impression of their instructor, possibly before even meeting them in-person; this study could not account for how students' perceptions of a teacher's mental illness disclosure might alter over the course of a semester, thus affecting its longitudinal validity.

\section{Limits to the Demographics}

In addition, there are obvious limitations to this study's findings in terms of its participants' demographics. The aforementioned participant data indicated that the majority of responses were heavily skewed white. This study's results largely do not take into account nonwhite experiences with the classroom, mental illness, disclosure, or the overlap among them. Because of the lack of diversity in the participants, responses did not reflect the greater hardships that non-white individuals often experience in similar contexts. Relatedly, participants of nonwestern nationalities were not largely represented in this study's participants, and, thus, 
neither were their opinions in the results. Therefore, this study's results are very Westernized and limited in their international scope.

Likewise, this study did not investigate gender or age differences, neither with its participants nor with its investigation of teachers. It is also possible that the results were skewed based on the self-identified genders of the participants, seeing that the majority of them identified as women. Addedly, this study did not utilize separate stimuli based on the disclosing teachers' genders, and, therefore, did not account for the effect this could have on the results. It also is possible that a portion of the results were skewed due to some of the participants' ages. Only a little more than half of this study's participants noted that they were aged 18-23, which is oftentimes the prime age for individuals to be enrolled in college classes; although, it is important to note that one can attend college at any time in their life, as education should not be dictated by agism. But, while at least half of participants were in the typical age group for college students that this study was hoping to target, the rest of the study was representative of answers from a wide age-range, thus impacting this study's ecological validity. This difference in age was likely limiting in some capacity for the study's analysis. Furthermore, this study did not investigate how this type of teacher self-disclosure might be perceived differently in different classrooms/departments (e.g., business-specific, psychology-specific, mathematics-specific), as this study primarily focused on studying generalized communication courses.

The state of participants' mental health could have also played a factor in skewing the results one way or another, thus, adding to the study's limitations. Seeing that the majority of participants indicated that they did not have a diagnosed mental illness and/or that their mental health was relatively good at the time of the survey, the results of this study are seemingly representative of those who have not directly experienced certain mental illness-related issues. It 
is possible that the study's results might have come out differently had more individuals living with a mental illness participated in the study. Although, the fact that $74.8 \%$ of participants reported that they have a family member or friend with a diagnosed mental illness hints that the participants in this study had a basic understanding of and compassion toward those living with a mental illness.

\section{Limits to the Materials}

In order to verify if the interactions among the study's three, independent variables were significant after the initial manipulation check, a post-hoc, Tukey HSD test was conducted on the main study with participants' answers to their individually assigned stimuli (see Appendix O). There was no statistically significant difference found among the null, partial, and full, despite the precautions taken prior to distributing materials to participants. Considering the concern of this, a follow-up, independent samples $t$-test was run to determine whether or not there was at least a significant difference between the partial and the full disclosure stimuli. Interestingly, a statistically significant difference was found when solely comparing the partial and full disclosure conditions. In order to ensure that this study's data was calculated to the best extent, an additional independent samples $t$-test was conducted to see if it would be better to analyze the data using only two stimuli groups, with the null group left as is and the partial and full disclosure conditions' results combined to represent a single, independent variable of general disclosure. While the results of this $t$-test were found to be statistically significant, calculating the data this way would have skewed the results and analysis, as the number of participants in this new, combined group would have doubled and created an unbalanced data set for the analysis. In light of this, this researcher deemed it appropriate to move forward with the results analyzed as the three, separate groups of disclosure, as initially intended. 


\section{Directions for Future Research}

\section{General, Variable-Based Directions}

Much research is still needed on innumerous facets of the topics this study explored, especially being that this study only begins to touch on some of the subject areas covered. While each variable from this study could be re-elaborated on and emphasized differently (e.g., syllabus-specific disclosure, disclosing a mental illness through different classroom mediums, different types of mental illness' stigmatizations differ and their impacts, etc.), it is safe to say that more research is needed for all of the variable subsets and intersections covered in this study. Certain variables warrant further investigation, although. Of note, teacher immediacy, both verbal and nonverbal, student motivation, and affective learning are all often discussed in tandem with many of the variables analyzed in this study (e.g., Hill, Ah Yun, \& Lindsey, 2008;

Miller, A. N. et al., 2014; Pogue \& Ahyun, 2006, and innumerous others). Future scholars should seek to interrogate different variables' impacts, as well as the current study's variables, on teacher self-disclosure to view a more holistic picture of this type of classroom-specific disclosure. Moreover, further research that looks at syllabus-disclosure of mental illness, and other classroom-related methods of disclosure, could be beneficial to the field, as well.

\section{Demographic-Focused Directions}

Additional research could also be conducted to investigate perceptional differences with this type of disclosure at other grade levels and age groups, as well. Few studies have delved into similar research exploring how this type of disclosure is impacted with students in different grades. For instance, the aforementioned Kauffman (2011) investigated similar disclosures of teachers specifically in the middle school setting, finding that "most of the middle school teachers viewed revealing personal information as a great way to build relationships, [and] all 
agreed that it is the best way to make the content tangible for the students" (p. 67). Similarly, investigations on this topic with emphases on other intersectional demographics (e.g., race, gender, class, etc.) that both teachers and future students will have are greatly needed.

Considering that mental illness affects everyone differently, and that non-white individuals must deal with the added, oppressive nature of the world on top of their mental health and possibly a mental illness, future research must accommodate to and recognize this privilege in order to unpack more non-white experiences in similar contexts, as well as those in non-Western contexts.

\section{Replication of Study}

There are multiple areas of this study that are in need of improvement, as indicated in the study's Limitations. An ideal place for one to start with a replication of this study would be to work more closely with the phrasing and grouping of the stimuli, as this study's stimuli did cause some problems along the way. As earlier implied, it might be worth looking into using only a null stimulus and a single stimulus with one level of disclosure in this same context. Just as this study did, future scholars looking into this research should ensure that they use multiple manipulation checks throughout their process, as it has clearly highlighted multiple limitations of this study that otherwise may have been overlooked. It is also likely that different scales regarding this study's variables would amount to different results, as well. In general, the Mental Illness Perceptions scale seemingly had much lower correlations with other scales than the all of the study's other scales had amongst each other. Perhaps an investigation into current correlations among this study's scales could lead to further findings, as well. Future research with similar tests should aim to use both the same and different scales for their measurements. The former would allow researchers to compare their results more directly to this study's results, 
and the latter would create a wider range of possibilities for the data's interpretation, as it could potentially complicate certain variables' definitions and create more discourse on the subject.

Another limitation stressed the possibility that the results might be indicative of the timing in which the disclosure was delivered (i.e., at the very start of the semester). It is possible that there may have been more statistically significant results had they been tested later in the hypothetical semester (i.e., disclosure not in the syllabus), as this would have allowed the participants and the teacher time to establish a bond and expectations in some capacity prior to the disclosure. Future research can attempt to comment on this possibility, perhaps by intentionally incorporating this form of disclosure at different points in the semester or by conducting a pre-test and a post-test to see if there is a tangible shift in participants' perspectives specifically from reading this disclosure in the syllabus. The latter suggestion would potentially implicate a greater timeframe and workload with participants, as they would have to commit to fully participating in the study multiple times.

Future scholars should also consider further investigating specific, statistical differences among participants' reported demographics. This study gathered general percentages to look for any face-value distinctions, but replications of this study should seek to perform more formal tests to find what, if any, significant trends occur with one demographic over another. For example, as $74.8 \%$ of this study's participants indicated they had a family member or friend with a diagnosed mental illness, future research should investigate whether or not this information plays a significant factor in this type of research. Future scholars could also look into finding correlations or differences, if there are any, in the responses to this study between participants who have a diagnosed mental illness and those who do not. 


\section{Conclusion}

In sum, this study investigated an instructor's level of mental illness disclosure in a syllabus and the impact it could have on student perceptions of mental illness, classroom climate, teacher credibility, homophily, and social attraction. As there has been scant research in many of the covered fields, particularly with teachers living with a mental illness, the current study attempted to address this lack in communicative mental health-related research. But, future research in this field is still highly recommended, as this analysis only begins to scratch the surface of this momentous topic.

Discussing mental health is essential to achieve authentic and productive student-teacher communication. The results of this study indicated that, despite the many stigmatizations that mentally ill individuals must endure, partial mental illness-related disclosures from instructors within their syllabi could help to reduce stigmatizations against mental illness. While mental health advocacy will never be completely finished, these results can at the very least provide hope for fellow teachers living with a mental illness that they are not alone. Change is possible, and this type of brave and vulnerable disclosure from willing teachers is only the first step to creating a world where the mentally ill can finally live stigma-free. 


\section{REFERENCES}

Abdullah, T., \& Brown, T. L. (2011). Mental illness stigma and ethnocultural beliefs, values, and norms: An integrative review. Clinical Psychology Review, 31, 934-948. doi:10.1016/j.cpr.2011.05.003

Allen, K. R. (1995). Opening the classroom closet: Sexual orientation and selfdisclosure. Family Relations, 44(2), 136-141. doi:10.2307/584799

American Psychiatric Association. (2018, August). What is mental illness? [Online article]. Retrieved from https:/www.psychiatry.org/patients-families/what-is-mental-illness

Andersen, K., \& Clevenger Jr., T. (1963). A summary of experimental research in ethos. Speech Monographs, 30(2), 59-78. doi:10.1080/03637756309375361

Ball, B., \& Strekalova, Y. A. (2020). Combatting mental health stigma in underserved black communities: A three-on-three basketball tournament intervention. In L. R. Lippert, R. D. Hall, A. E. Miller-Ott, \& D. C. Davis (Eds.), Communicating mental health (pp. 217235). Lanham, MD: Lexington Books.

Banfield, S. R., Richmond, V. P., \& McCroskey, J. C. (2006). The effect of teacher misbehaviors on teacher credibility and affect for the teacher. Communication Education, 55(1), 63 72. doi:10.1080/03634520500343400

Barile, N. (n.d.) The importance of mental health awareness in schools [Online article]. Retrieved from https://www.wgu.edu/heyteach/article/importance-mental-healthawareness-schools1810.html

Berry, N., Lobban, F., Belousov, M., Emsley, R., Nenadic, G., \& Bucci, S. (2017). \#WhyWeTweetMH: Understanding why people use Twitter to discuss mental health problems. Journal of Medical Internet Research, 19(4). doi:10.2196/jmir.6173 
Berscheid, E., \& Hatfield Walster, E. (1969). Interpersonal communication [Online version]. Retrieved from http://www.sexarchive.info/BIB/HTF/IA.htm

Bodie, G. D. (2010). A racing heart, rattling knees, and ruminative thoughts: Defining, explaining, and treating public speaking anxiety. Communication Education, 59(1), 70105. doi:10.1080/03634520903443849

Boren, J. P., \& McPherson, M. B. (2018). Is coming out in the classroom still an occupational hazard? A replication of Russ, Simonds, and Hunt (2002). Communication Studies, 69(3), 242-250. doi:10.1080/10510974.2018.1466719

Borzea, D., \& Goodboy, A. K. (2016). When instructors self-disclose but misbehave: Conditional effects on student engagement and interest. Communication Studies, 67(5), 548-566. doi:10.1080/10510974.2016.1212912

Bower-Phipps, L. (2017). Discourses governing Lesbian, Gay, Bisexual, Transgender, Queer, Intersex, and Asexual teachers' disclosure of sexual orientation and gender history. Issues in Teacher Education, 26(3), 23-37. Retrieved from https://eric.ed.gov/?id=EJ1157784

Bowers, H., Manion, I., Papadopoulos, D., \& Gauvreau, E. (2013). Stigma in school-based mental health: Perceptions of young people and service providers. Child and Adolescent Mental Health, 18(3), 165-170. doi:10.1111/j.1475-3588.2012.00673.x

Brophy, N. S. (2018). The effects of instructors discussing alcohol in the classroom on student perceptions of their instructor (Master's thesis). Retrieved from ISU ReD: Research and eData.

Brown, R. L., Moloney, M. E., \& Brown, J. (2018). Gender differences in the processes linking public stigma and self-disclosure among college students with mental illness. Journal of Community Psychology, 46(2), 202-212. doi:10.1002/jcop.21933 
Brown, S. L. (2002). Teaching preventive mental health skills to functional college students: A comparison of three classroom-based interventions. Dissertation Abstracts International: Section B. Sciences and Engineering, 62(9-B), 3966.

Bureau of Census for the Bureau of Labor Statistics. (2018). Current population survey (HOUSEHOLD DATA ANNUAL AVERAGES: 11b. Employed persons by detailed occupation and age). Retrieved from https://www.bls.gov/cps/cpsaat11b.pdf

Campbell, R. D. (2018). Disclosure in teaching: Using personal mental health experiences to facilitate teaching and learning in clinical social work practice. Reflections: Narratives of Professional Helping, 24(2), 44-48. Retrieved from

https://reflectionsnarrativesofprofessionalhelping.org/index.php/Reflections/article/view/ $1644 / 1541$

Cayanus, J. L. (2004). "Effective instructional practice": Using teacher self-disclosure as an instructional tool. Communication Teacher, 18(1), 6-9. doi:10.1080/1740462032000142095

Cayanus, J., \& Martin, M. (2008). Teacher self-disclosure: Amount, relevance, and negativity. Communication Quarterly, 56(3), 325-341. doi:10.1080/01463370802241492

Chakravorti, D., Law, K., Gemmel, J., \& Raicu, D. (2018, November). Detecting and characterizing trends in online mental health discussions. In H. Tong, Z. Li, F. Zhu, J. Yu (Eds.), $18^{\text {th }}$ IEEE International Conference on Data Mining Workshops (ICDMW) (pp. 697-706). doi:10.1109/ICDMW.2018.00107

Coker, J. M., \& Cain, L. K. (2018). Southern disclosure: One southern-and-queer middle school teacher's narrative. Middle Grades Review, 4(3), 1-9. Retrieved from https://files.eric.ed.gov/fulltext/EJ1201233.pdf 
Corrigan, P., \& Matthews, A. (2003). Stigma and disclosure: Implications for coming out of the closet. Journal of Mental Health, 12(3), 235-248. doi:10.1080/0963823031000118221

Corrigan, P. W., Kosyluk, K. A., Markowitz, F., Brown, R. L., Conlon, B., Rees, J.,... AlKhouja, M. (2016). Mental illness stigma and disclosure in college students. Journal of Mental Health, 25(3), 224-230. doi:10.3109/09638237.2015.1101056

Corrigan, P. W., Morris, S. B., Michaels, P. J., Rafacz, J. D., \& Rüsch, N. (2012). Challenging the public stigma of mental illness: A meta-analysis of outcome studies. Psychiatric Services, 63(10), 963-973. doi:10.1176/appi.ps.201100529

Craig, E. A., \& Moore, J. (2020). Mental illness, ambiguous loss, and communicative resilience in families. In L. R. Lippert, R. D. Hall, A. E. Miller-Ott, \& D. C. Davis (Eds.), Communicating mental health (pp. 239-256). Lanham, MD: Lexington Books.

Cramer, E. P. (1997). Effects of an educational unit about Lesbian identity development and disclosure in a social work methods course. Journal of Social Work Education, 33(3), 461-472. doi:10.1080/10437797.1997.10778886

Curran, T., \& Scharp, K. M. (2020). Conflict communication in families and mental health outcomes for parents: Examining mother and father reports of depressive and anxiety symptoms, verbal aggression, and constructive conflict. In L. R. Lippert, R. D. Hall, A. E. Miller-Ott, \& D. C. Davis (Eds.), Communicating mental health (pp. 257-272). Lanham, MD: Lexington Books.

Curtis, D. A., \& Moore, K. (2018). The first day of class: Starting with an activity or syllabus? North American Journal of Psychology, 20(3), 653-670. Retrieved from https://www.researchgate.net/publication/328938622_The_First_Day_of_Class_Starting_ With_an_Activity_or_Syllabus 
Daw, J., Margolis, R., \& Verdery, A. M. (2015). Siblings, friends, course-mates, club-mates: How adolescent health behavior homophily varies by race, class, gender, and health status. Social Science \& Medicine, 125, 32-39. doi:10.1016/j.socscimed.2014.02.047

de Boer, P, \& Bordoloi, P. (2018, May). Exploring instructor evaluation, affective learning and teacher credibility in international classrooms. Paper presented at the Cross Cultural Business Conference, Steyr, Austria.

Delaney, A. L., \& Basinger, E. D. (2020). Depression in romantic relationships: Integrating social constructionist perspectives. In L. R. Lippert, R. D. Hall, A. E. Miller-Ott, \& D. C. Davis (Eds.), Communicating mental health (pp. 331-349). Lanham, MD: Lexington Books.

Docan-Morgan, T. (2011). "Everything changed": Relational turning point events in college teacher-student relationships from teachers' perspectives. Communication Education, 60(1), 20-50. doi:10.1080/03634523.2010.497223

Doll, B., Nastasi, B. K., Cornell, L., \& Song, S. Y. (2017). School-based mental health services: Definitions and models of effective practice. Journal of Applied School Psychology, 33(3), 179-194. doi:10.1080/15377903.2017.1317143

Echols, L., \& Graham, S. (2013). Birds of a different feather: How do cross-ethnic friends flock together? Merrill-Palmer Quarterly, 59(4), 461-488. doi:10.1353/mpq.2013.0020

Eisenberg, D., Downs, M. F., Golberstein, E., \& Zivin, K. (2009). Stigma and help seeking for mental health among college students. Medical Care Research and Review, 66(5), 522541. doi:10.1177/1077558709335173 
Eisenberg, D., Hunt, J., \& Speer, N. (2013). Mental health in American colleges and universities: Variation across student subgroups and across campuses. The Journal of Nervous and Mental Disease, 201(1), 60-67. doi:10.1097/NMD.0b013e31827ab077

Fahey, L., \& Randell, R. (1998). Learning from the future: Competitive foresight scenarios. New York, NY: John Wiley \& Sons.

Fisher Clune, M. K. (2009). Students' perceptions of instructor credibility: Effects of instructor sex, gender role, and communication style (Doctoral dissertation). Retrieved from https://kuscholarworks.ku.edu/bitstream/handle/1808/5973/Clune_ku_0099D_10590_DA TA_1.pdf?sequence $=1$

Flood-Grady, E., Kellas, J. K., \& Chernin, K. A. (2020). Communicated sense-making: A theoretical compass for exploring family communication and sense-making about mental health and illness. In L. R. Lippert, R. D. Hall, A. E. Miller-Ott, \& D. C. Davis (Eds.), Communicating mental health (pp. 27-52). Lanham, MD: Lexington Books.

Fraser, B. J. (1994). Research on classroom and school climate. In D. Gabel (Ed.), Handbook of research on science teaching and learning (pp. 493-541). New York, NY: Macmillan.

Fraser, B. J. (1998). Science learning environments: Assessment, effects and determinants. In B. J. Fraser \& K. G. Tobin (Eds.), International handbook of science education (pp. 527564). Dordrecht, The Netherlands: Kluwer.

Fraser, B. J. (1999). Using Learning environment assessments to improve classroom and school climates. In H. J. Freiberg (Ed.), School climate: Measuring, improving, and sustaining healthy learning environments (pp. 65-83). Philadelphia, PA: Taylor and Francis.

Fraser, B. J. (2012). Classroom environment. New York, NY: Routledge. 
Frymier, A. B., \& Houser, M. L. (2000). The teacher-student relationship as an interpersonal relationship. Communication Education, 49(3), 207-219.

doi: $10.1080 / 03634520009379209$

Gilchrist-Petty, E. C. (2017). Unraveling complexities in the teacher-student relationship: perceptions of immediacy, credibility, and learning. Carolinas Communication Annual, 33, 45-61. Retrieved from https://carolinascommunication.files.wordpress.com/2018/02/2017carolinascommunicationannual.pdf

Gokcora, D. (1989, November). A descriptive study of communication and teaching strategies used by two types of international teaching assistants at the University of Minnesota, and their cultural perceptions of teaching and teachers. Paper presented at the meeting of the National Conference on Training and Employment of Teaching Assistants, Seattle, WA.

Goldman, Z. W. (2018). Responding to mental health issues in the college classroom. Communication Education, 67(3), 399-404. doi:10.1080/03634523.2018.1465191

Goodboy, A. K., Carton, S. T., Goldman, Z. W., Gozanski, T. A., Tyler, W. J. C., \& Johnson, N. R. (2014). Discouraging instructional dissent and facilitating students' learning experiences through instructor self-disclosure. Southern Communication Journal, 79(2), 114-129. doi:10.1080/1041794X.2013.865256

Gorham, J., Cohen, S. H., \& Morris, T. L. (1997). Fashion in the classroom II: Instructor immediacy and attire. Communication Research Reports, 14(1), 11-23. doi:10.1080/08824099709388641

Gross Davis, B. (2009). Tools for teaching (2nd ed.). San Francisco, CA: Jossey-Bass. 
Hagmajer, D., \& Strekalova, Y. A. (2020). When healthcare professionals need help: Nursing burnout and supportive communication. In L. R. Lippert, R. D. Hall, A. E. Miller-Ott, \& D. C. Davis (Eds.), Communicating mental health (pp. 187-200). Lanham, MD: Lexington Books.

Hall, R. D., \& Miller-Ott, A. E. (2020). Communicating about mental health: What we know, what we need, and what we give. In L. R. Lippert, R. D. Hall, A. E. Miller-Ott, \& D. C. Davis (Eds.), Communicating mental health (pp. 3-10). Lanham, MD: Lexington Books.

Hartel, J., Nguyen, A. T., \& Guzik, E. (2017). Mindfulness meditation in the classroom. Journal of Education for Library \& Information Science, 58(2), 112-115. doi:10.12783/issn.2328-2967/58/2/6

Hatzenbuehler, M. L., Phelan, J. C., \& Link, B. G. (2013). Stigma as a fundamental cause of population health inequalities. American Journal of Public Health, 103(5), 813-821. doi:10.2105/AJPH.2012.301069

Hayward, P. A. (2003). Effectively approaching the first day of class. Communication Teacher, 17(3), 3-16.

Helens-Hart, R. (2017). Females' (non)disclosure of minority sexual identities in the workplace from a Communication Privacy Management perspective. Communication Studies, 68(5), 607-623. doi:10.1080/10510974.2017.1388827

Henningsen, M. L. M., Valde, K. S., Entzminger, M. J., Dick, D. T., \& Wilcher, L. B. (2019). Student disclosures about academic information: Student privacy rules and boundaries. Communication Reports, 32(1), 29-42. doi:10.1080/08934215.2018.1556312 
Henslee, A. M., Burgess, D. R., \& Buskist, W. (2006). Student preferences for first day of class activities. Teaching of Psychology, 33(3), 189-191. Retrieved from https://psycnet.apa.org/record/2006-09795-007

Hill, J., Ah Yun, K., \& Lindsey, L. (2008). The interaction effect of teacher self-disclosure valence and relevance on student motivation, teacher liking, and teacher immediacy. Paper presented at the National Communication Association, San Diego, CA.

Hoffner, C. A. (2020). Responses to celebrity mental health disclosures: Parasocial relations, evaluations, and perceived media influence. In L. R. Lippert, R. D. Hall, A. E. Miller-Ott, \& D. C. Davis (Eds.), Communicating mental health (pp. 125-146). Lanham, MD: Lexington Books.

Horan, S. M., Houser, M. L., Goodboy, A. K., \& Frymier, A. B. (2011). Students’ early impressions of instructors: Understanding the role of relational skills and messages. Communication Research Reports, 28(1), 74-85. doi:10.1080/08824096.2011.541362

Hosek, A. M., \& Presley, R. (2018). College student perceptions of the (in)appropriateness and functions of teacher disclosure. College Teaching, 66(2), 63-72. doi:10.1080/87567555.2017.1385587

Hosek, A. M., \& Thompson, J. (2009). Communication privacy management and college instruction: Exploring the rules and boundaries that frame instructor private disclosures. Communication Education, 58(3), 327-349. doi:10.1080/03634520902777585

Imlawi, J., \& Gregg, D. (2014). Engagement in online social networks: The impact of selfdisclosure and humor. International Journal of Human-Computer Interaction, 30(2), 106-125. doi:10.1080/10447318.2013.839901 
Imlawi, J., Gregg, D., \& Karimi, J. (2015). Student engagement in course-based social networks: The impact of instructor credibility and use of communication. Computers \& Education, 88, 84-96. doi:10.1016/j.compedu.2015.04.015

Jabbar, H., \& Hussain, H. (2017). Role of syllabus in developing cultural equity in school a comparative study of public \& private sectors in Pakistan. Language in India, 17(4), 4662. Retrieved from http://www.languageinindia.com/april2017/humeraculturesyllabus.pdf

Jenkins, J. S., Bugeja, A. D., \& Barber, L. K. (2014). More content or more policy? A closer look at syllabus detail, instructor gender, and perceptions of instructor effectiveness. College Teaching, 62(4), 129-135. doi:10.1080/87567555.2014.935700

Johnsen, L. J., Robinson, T., \& Luckasen, C. (2017). Communication Privacy Management and learning disabilities in the classroom: Understanding students' rules for disclosure. Florida Communication Journal, 45(2), 13-27.

Jugert, P., Leszczensky, L., \& Pink, S. (2018). The effects of ethnic minority adolescents' ethnic self-identification on friendship selection. Journal of Research on Adolescence, 28(2), 379-395. doi:10.1111/jora.12337

Jugert, P., Rutland, A., Brown, R., Cameron, L., Nigbur, D., Watters, C., ... Le Touze, D. (2017). Increasing ethnic diversity moderates longitudinal effects of individual differences on friendship homophily. Journal of Community \& Applied Social Psychology, 27(5), 411-423. doi:10.1002/casp.2319

Kaufmann, R. M. (2011). Teacher disclosure: Developing privacy rules managing boundaries and building relationships (Master's thesis). Retrieved from https://uknowledge.uky.edu/gradschool_theses/154 
Kaufmann, R., \& Lane, D. (2014). Examining communication privacy management in the middle school classroom: Perceived gains and consequences. Educational Research, 56(1), 13-27. doi:10.1080/00131881.2013.874145

Keppel, G. (1991). Design and analysis: A researcher's handbook (3 ${ }^{\text {rd }}$ ed.). Upper Saddle River, NJ: Prentice-Hall, Inc.

Keyton, J. (2011). Communication research asking questions, finding answers ( $3^{\text {rd }}$ ed). New York, NY: McGraw-Hill.

Klebig, B., Goldonowicz, J., Mendes, E., Miller, A. N., \& Katt, J. (2016). The combined effects of instructor communicative behaviors, instructor credibility, and student personality trains on incivility in the college classroom. Communication Research Reports, 33, 152158. doi:10.1080/08824096.2016.1154837

Kranke, D. Jackson, S. E., Taylor, D. A., Anderson-Fye, E., \& Floersch, J. (2013). College student disclosure of non-apparent disabilities to receive classroom accommodations. Journal of Postsecondary Education and Disability, 26(1), 35-51. Retrieved from https://files.eric.ed.gov/fulltext/EJ1026808.pdf

Kreps, G. L. (2020). The chilling influences of social stigma on mental health communication: Implications for promoting health equity. In L. R. Lippert, R. D. Hall, A. E. Miller-Ott, \& D. C. Davis (Eds.), Communicating mental health (pp. 11-24). Lanham, MD: Lexington Books.

Lannutti, P. J., \& Strauman, E. C. (2006). Classroom communication: The influence of instructor self-disclosure on student evaluations. Communication Quarterly, 54(1), 89-99. doi:10.1080/01463370500270496 
Ledbetter, A. M., \& Finn, A. N. (2018). Perceived teacher credibility and students' affect as a function of instructors' use of PowerPoint and email. Communication Education, 67(1), 31-51. doi:10.1080/03634523.2017.1385821

Leeds, J. D. (1992, August). The course syllabus as seen by the undergraduate student. Paper presented at the annual meeting of the American Psychological Association, Washington, DC.

Levecque, K., Anseel, F., Beuckelaer, A. D., Van der Heyden, J., \& Gisle, L. (2017). Work organization and mental health problems in PhD students. Research Policy, 46, 868-879. doi:10.1016/j.respol.2017.02.008

Liddle, B. J. (1997). Coming out in class: Disclosure of sexual orientation and teaching evaluations. Teaching of Psychology, 24(1), 32-35. doi:10.1207/s15328023top2401_6

López, V., Torres-Vallejos, J., Ascorra, P., Villalobos-Parada, B., Bilbao, M., \& Valdés, R. (2018). Construction and validation of a classroom climate scale: A mixed methods approach. Learning Environments Research, 21(1), 407-422. doi:10.1007/s10984-0189258-0

Mamas, C., Daly, A. J., Struyve, C., Kaimi, I., \& Michail, G. (2019). Learning, friendship and social contexts: Introducing a social network analysis toolkit for socially responsive classrooms. International Journal of Educational Management, 33(6), 1255-1270. doi:10.1108/IJEM-03-2018-0103

Martin, M. M., Myers, S. A., \& Mottet, T. P. (1999). Students' motives for communicating with their instructors. Communication Education, 48, 155-164. doi:10.80/03634529909379163 
Mayo Clinic Staff. (2017, May 24). Mental health: Overcoming the stigma of mental illness. Retrieved from https://www.mayoclinic.org/diseases-conditions/mental-illness/indepth/mental-health/art-20046477

Mazer, J., Murphy, R., \& Simonds, C. (2009). The effects of teacher self-disclosure via Facebook on teacher credibility. Learning, Media, and Technology, 34(2), 175-183. doi:10.1080/17439880902923655

Mazer, J. P., \& Stowe, S. A. (2016). Can teacher immediacy reduce the impact of verbal aggressiveness? Examining effects on student outcomes and perceptions of teacher credibility. Western Journal of Communication, 80(1), 21-37. doi:10.1080/10570314.2014.943421

McBride, M. C., \& Wahl, S. T. (2005). “To say or not to say:” Teachers' management of privacy boundaries in the classroom. Texas Speech Communication Journal, 30(1), 8-22.

McCormick, M. P., Cappella, E., Hughes, D. L., \& Gallagher, E. K. (2015). Feasible, rigorous, and relevant: Validation of a measure of friendship homophily for diverse classrooms. Journal of Early Adolescence, 35(5-6), 817-851. doi:10.1177/0272431614547051

McCroskey, J. C. (1977). Classroom consequences of communication apprehension. Communication Education, 26, 27-33. doi:10.1080/03634527709378196

McCroskey, J. C., \& McCain, T. A. (1974, August). The measurement of interpersonal attraction. Communication Monographs, 41, 261-266. doi:10.1080/03637757409375845

McCroskey, J. C., Richmond, V. P., \& Daly, J. A. (1975). The development of a measure of perceived homophily. Human Communication Interaction, 1, 323-332. doi:10.1111/j.1468-2958.1975.tb00281.x. 
McCroskey, J. C., \& Teven, J. J. (1999). Goodwill: A reexamination of the construct and its measurement. Communication Monographs, 66, 90-103. doi:10.1080/03637759909376464

McCroskey, J. C., \& Young, T. J. (1981). Ethos and credibility: The construct and its measurement after three decades. Central States Speech Journal, 32(1), 2434. doi:10.1080/10510978109368075

McCroskey, L. L., McCroskey, J. C., \& Richmond, V. P. (2006). Analysis and improvement of the measurement of interpersonal attraction and homophily. Communication Quarterly, 54(1), 1-32. doi:10.1080/01463370500270322

McKenna-Buchanan, T., Munz, S., \& Rudnick, J. (2015). To be or not to be out in the classroom: Exploring communication privacy management strategies of Lesbian, Gay, and Queer college teachers. Communication Education, 64(3), 280-300. doi: $10.1080 / 03634523.2015 .1014385$

McLemore, D. M. (2020). Dangerous and disturbed: Media misportrayals of mental illness. In L. R. Lippert, R. D. Hall, A. E. Miller-Ott, \& D. C. Davis (Eds.), Communicating mental health (pp. 309-330). Lanham, MD: Lexington Books.

McPherson, M., Smith-Lovin, L., \& Cook, J. M. (2001). Birds of a feather: Homophily in social networks. Annual Review of Psychology, 27(1), 415-444. Retrieved from http://aris.ss.uci.edu/ /in/52.pdf

Meluch, A., Feehan, K., \& Starcher, S. (2019). Instructor disclosures of communication apprehension and student perceptions of instructor credibility in the public speaking classroom. International Journal of Teaching and Learning in Higher Education, 31(2), 299-309. Retrieved from https://files.eric.ed.gov/fulltext/EJ1224345.pdf 
Meluch, A. L., \& Starcher, S. (2020). The stigmatization of mental health disclosure in the college classroom: Student perceptions of instructor credibility and the benefits of disclosure. In L. R. Lippert, R. D. Hall, A. E. Miller-Ott, \& D. C. Davis (Eds.), Communicating mental health (pp. 147-166). Lanham, MD: Lexington Books.

Mietzner, D., \& Reger, G. (2005). Advantages and disadvantages of scenario approaches for strategic foresight. International Journal of Technology Intelligence and Planning, 1(2), 220-239. Retrieved from http://www.forschungsnetzwerk.at/downloadpub/stragegicforesight2005.pdf

Miller, A. N., Katt, J. A., Brown, T., \& Sivo, S. A. (2014). The relationship of instructor selfdisclosure, nonverbal immediacy, and credibility to student incivility in the college classroom. Communication Education, 63(1), 1-16. doi:10.1080/03634523.2013.835054

Miller, C. J., Borsatto, J., \& Al-Salom, P. (2019). Testing a quick mindfulness intervention in the university classroom. Journal of Further \& Higher Education, 43(6), 839-847. doi:10.1080/0309877X.2017.1409345

Minger, S. R. (2004). Student empowerment and learning within the instructor-student relationship: Student outcomes mediated by instructor self-disclosure, perceived instructor caring, and relational solidarity (Doctoral dissertation). Retrieved from ProQuest Information and Learning Company.

Mollica, K. A., Gray, B., \& Treviño, L. K. (2003). Racial homophily and its persistence in newcomers' social networks. Organization Science, 14(2), 123-136. doi:10.1287/orsc.14.2.123.14994 
Morris, T. L., Gorham, J., Cohen, S. H., \& Huffman, D. (1996). Fashion in the classroom: Effects of attire on student perceptions of instructors in college classes. Communication Education, 45, 135-148. doi:10.1080/03634529609379043

Moses, T. (2010). Being treated differently: Stigma experiences with family, peers, and school staff among adolescents with mental health disorders. Social Science \& Medicine, 70, 985-993. doi:10.1016/j.socscimed.2009.12.022

Myers, S. A. (2001). Perceived instructor credibility and verbal aggressiveness in the college classroom. Communication Research Reports, 18, 354-364. doi: $10.1080 / 03634523.2013 .835054$

Myers, S. A., Brann, M., \& Members of Comm 600. (2009). College students' perceptions of how instructors establish and enhance credibility through self-disclosure. Qualitative Research Reports in Communication, 10(1), 9-16. doi:10.1080/17459430902751808

Myers, S. A., \& Huebner, A. D. (2011). The relationship between students' motives to communicate with their instructors and perceived instructor credibility, attractiveness, and homophily. College Student Journal, 45(1), 84-91. Retrieved from https://go.gale.com/ps/anonymous?id=GALE\%7CA252632759\&sid=googleScholar\&v= $2.1 \& \mathrm{it}=\mathrm{r} \&$ linkaccess $=\mathrm{abs} \& \mathrm{issn}=01463934 \& \mathrm{p}=\mathrm{AONE} \& \mathrm{sw}=\mathrm{w}$

National Alliance on Mental Health. (2012). College students speak: A survey report on mental health. Retrieved from https://www.nami.org/About-NAMI/Publications-Reports/SurveyReports/College-Students-Speak_A-Survey-Report-on-Mental-H.pdf

National Institute of Mental Health. (2018, January 29). Mental illness by the numbers. Retrieved from https://www.nimh.nih.gov/news/science-news/2018/mental-illnesses-bythe-numbers.shtml 
National Institute of Mental Health. (2019, February). Mental illness. Retrieved from https://www.nimh.nih.gov/health/statistics/mental-illness.shtml

Nodulman, J. (2011). The secret life of your classmates: Understanding Communication Privacy Management. Communication Teacher, 25(4), 218-221. doi:10.1080/17404622.2011.601723

Obermiller, C., Ruppert, B., \& Atwood, A. (2012). Instructor credibility across disciplines: Identifying students' differentiated expectations of instructor behaviors. Business Communication Quarterly, 75(2), 153-165. doi:10.1177/1080569911434826

Orlov, J. M., \& Allen, K. R. (2014). Being who I am: Effective teaching, learning, student support, and societal change through LGBQ faculty freedom. Journal of Homosexuality, 61(7), 1025-1052. doi:10.1080/00918369.2014.870850

Palmer, M. S., Wheeler, L. B., \& Aneece, I. (2016). Does the document matter? The evolving role of syllabi in higher education. Change, 48(4), 36-47. doi:10.1080/00091383.2016.1198186

Parkes, J., \& Harris, M. B. (2002). The purposes of a syllabus. College Teaching, 50(2), 55-61. Retrieved from https://jan.ucc.nau.edu/ coesyl-p/syllabus_cline_article_2.pdf

Perry, B. L., \& Pescosolido, B. A. (2015). Social network activation: The role of health discussion partners in recovery from mental illness. Social Science \& Medicine, 125, 116-128. doi:10.1016/j.socscimed.2013.12.033

Petronio, S. S. (2002). Boundaries of privacy: Dialectics of disclosure. Albany, NY: State University of New York Press.

Petronio, S. (2013). Brief status report on Communication Privacy Management Theory. Journal of Family Communication, 13, 6-14. doi:10.1080/15267431.2013.743426 
Piercy, C. W., \& Zanin, A. C. (2020). Community-based mental healthcare: A network analysis of identification and involvement in an advocacy group. In L. R. Lippert, R. D. Hall, A. E. Miller-Ott, \& D. C. Davis (Eds.), Communicating mental health (pp. 167-186). Lanham, MD: Lexington Books.

Pogue, L. L., \& Ahyun, K. (2006). The effect of teacher nonverbal immediacy and credibility on student motivation and affective learning. Communication Education, 55(3), 331-344. doi:10.1080/03634520600748623

Powell, L., Hamilton, T., Hickson III, M., \& Stuckey, J. (2001). The relationship of homophily to verbal and nonverbal immediacy in the classroom. Communication Research Reports, 18(3), 217-222. doi:10.1080/08824090109384801

Price, M., \& Kerschbaum, S. L. (2017). Promoting supportive academic environments for faculty with mental illness: Resource guide and suggestions for practice. National Institute on Disability, Independent Living, and Rehabilitation Research: Temple University Collaborative. Retrieved from http://www.tucollaborative.org/sdm_downloads/supportive-academic-environments-forfaculty-with-mental-illnesses/

Price, M., Salzer, M. S., O’Shea, A., \& Kerschbaum, S. L. (2017). Disclosure of mental disability by college and university faculty: The negotiation of accommodations, supports, and barriers. Disability Studies Quarterly, 37(2). doi:10.18061/dsq.v37i2.5487

Price, S. F., Carmack, H. J., \& Kuang, K. (2020). Contradictions and predicaments in instructors' boundary negotiations of students' health disclosures. Health Communication, 1-9. doi:10.1080/10410236.2020.1712525 
Quintero Johnson, J. M., Yilmaz, G., \& Najarian, K. (2017). Optimizing the presentation of mental health information in social media: The effects of health testimonials and platform on source perceptions, message processing, and health outcomes. Health Communication, 32(9), 1121-1132. doi:10.1080/10410236.2016.1214218

Ramirez, R., Mukherjee, M., Vezzoli, S., \& Kramer, A. M. (2015). Scenarios as a scholarly methodology to produce "interesting research." Elsevier: Futures, 71, 70-87. doi:10.1016/j.futures.2015.06.006

Reevy, G. M., \& Deason, G. (2014). Predictors of depression, stress, and anxiety among nontenure track faculty. Frontiers in Psychology, 5, 1-17. doi:10.3389/fpsyg.2014.00701

Renuka Uthappa, N. (2018). The uses of disclosure: Building a rhetorical scaffolding to fight stigma in the writing classroom. Pedagogy, 18(3), 566-572. doi:10.1215/153142006937035

Robinson, D. (2019). Engaging students on the first day of class: Student-generated questions promote positive course expectations. Scholarship of Teaching and Learning in Psychology, 5(3), 183-188. doi:10.1037/st10000139

Rocca, K. A., \& McCroskey, J. C. (1999). The interrelationship of student ratings of instructors' immediacy, verbal aggressiveness, homophily, and interpersonal attraction. Communication Education, 48(4), 308-316. doi:10.1080/03634529909379181

Roeser, R. W., \& Eccles, J. S. (2014). Schooling and the mental health of children and adolescents in the United States. In M. Lewis \& K. D. Rudolph (Eds.), Handbook of developmental psychopathology (3rd ed.) (pp. 163-184). doi:10.1007/978-1-4614-9608-3 
Rowe, E. W., Kim, S., Baker, J. A., Kamphaus, R. W., \& Horne, A. M. (2010). Student personal perception of classroom climate: Exploratory and confirmatory factor analyses.

Educational and Psychological Measurement, 70(5), 858-879.

doi: $10.1177 / 0013164410378085$

Rudick, C. K., \& Dannels, D. P. (2018). Yes, and*...: continuing the scholarly conversation about mental health stigma in higher education. Communication Education, 67(3), 404408. doi:10.1080/03634523.2018.1467563

Rudnick, J. J. (2012). To share or not to share: The impact of disclosing sexuality on instructor communication apprehension, instructional effectiveness, and student relationships (Master's thesis). Retrieved from Cornerstone: A Collection of Scholarly and Creative Works for Minnesota State University, Mankato.

Rüsch, N., Angermeyer, M. C., \& Corrigan, P. W. (2005). Mental illness stigma: Concepts, consequences, and initiatives to reduce stigma. European Psychiatry, 20(8), 529-539. doi:10.1016/j.eurpsy.2005.04.004

Russ, T. L., Simonds, C. J., \& Hunt, S. K. (2002). Coming out in the classroom... an occupational hazard: The influence of sexual orientation on teacher credibility and perceived student learning. Communication Education, 51(3), 311-324. doi:10.1080/03634520216516

Samp, J. A., \& Cohen, A. I. (2020). Managing moral injury post-deployment. In L. R. Lippert, R. D. Hall, A. E. Miller-Ott, \& D. C. Davis (Eds.), Communicating mental health (pp. 201216). Lanham, MD: Lexington Books. 
Schrodt, P. (2013). Content relevance and students' comfort with disclosure as moderators of instructor disclosures and credibility in the college classroom. Communication Education, 62(4), 352-375. doi:10.1080/03634523.2013.807348

Sidelinger, R. J., Nyeste, M. C., Madlock, P. E., Pollak, J., \& Wilkinson, J. (2015). Instructor privacy management in the classroom: Exploring instructors' ineffective communication and student communication satisfaction. Communication Studies, 66(5), 569-589. doi:10.1080/10510974.2015.1034875

Simonds, C. J., \& Hooker, J. F. (2018). Creating a culture of accommodation in the public speaking course. Communication Education, 67(3), 393-399. doi:10.1080/03634523.2018.1465190

Smirnov, I., \& Thurner, S. (2017). Formation of homophily in academic performance: Students change their friends rather than performance. PLoS ONE, 12(8), 1-16. doi:10.1371/journal.pone. 0183473

Smith, R. A. (2007). Language of the lost: An explication of stigma communication. Communication Theory, 17(4), 462-485. doi:10.1111/j.1468-2885.2007.00307.x

Smith, R. A., \& Applegate, A. (2018). Mental health stigma and communication and their intersections with education. Communication Education, 67(3), 382-393. doi:10.1080/03634523.2018.1465988

Smith-Frigerio, S. (2020). "Warrior moms": Stigma management communication and advocacy on postpartum progress concerning maternal mental health concerns. In L. R. Lippert, R. D. Hall, A. E. Miller-Ott, \& D. C. Davis (Eds.), Communicating mental health (pp. 273292). Lanham, MD: Lexington Books. 
Smith-Tran, A. (2019). Exploring the benefits and drawbacks of age disclosure among women faculty of color. Teaching Sociology, 1-10. doi:10.1177/0092055X19869983

Song, H., Kim, J., \& Park, N. (2019). I know my professor: Teacher self-disclosure in online education and a mediating role of social presence. International Journal of HumanComputer Interaction, 35(6), 448-455. doi:10.1080/10447318.2018.1455126

Sorensen, G. (1989). The relationships among teachers' self-disclosive statements, students' perceptions, and affective learning. Communication Education, 38(3), 259-276. doi:10.1080/03634528909378762

Šouláková, B., Kasal, A., Butzer, B., \& Winkler, P. (2019). Meta-review on the effectiveness of classroom-based psychological interventions aimed at improving student mental health and well-being, and preventing mental illness. The Journal of Primary Prevention, 40(3), 255-278. doi:10.1007/s10935-019-00552-5

Stein, D. J., Phillips, K. A., Bolton, D., Fulford, K. W., Sadler, J. Z., \& Kendler, K. S. (2010). What is a mental/psychiatric disorder? From DSM-IV to DSM-V. Psychological Medicine, 40(11), 1759-1765. doi:10.1017/S0033291709992261

Substance Abuse and Mental Health Services Administration. (2019). Key substance use and mental health indicators in the United States: Results from the 2018 National Survey on Drug Use and Health (HHS Publication No. PEP19-5068, NSDUH Series H-54). Rockville, MD: Center for Behavioral Health Statistics and Quality, Substance Abuse and Mental Health Services Administration. Retrieved from https://www.samhsa.gov/data/

Teven, J. J. (2001). The relationships among teacher characteristics and perceived caring. Communication Education, 50(2), 159-169. doi:10.1080/03634520109379241 
Teven, J. J. (2007). Teacher caring and classroom behavior: Relationships with student affect and perceptions of teacher competence and trustworthiness. Communication Quarterly, 55(4), 433-450. doi:10.1080/01463370701658077

Teven, J. J., \& Hanson, T. L. (2004). The impact of teacher immediacy and perceived caring on teacher competence and trustworthiness. Communication Quarterly, 52(1), 39-53. doi:10.1080/01463370409370177

Teven, J. J., \& McCroskey, J. (1997). The relationship of perceived teacher caring with student learning and teacher evaluation. Communication Education, 46, 1-9. doi:10.1080/03634529709379069

Thweatt, K. S., \& McCroskey, J. C. (1998). The impact of teacher immediacy and misbehaviors on teacher credibility. Communication Education, 47(4), 348-358. doi:10.1080/03634529809379141

Toppo, G. (2017, October 30). Survey: Teachers' mental health declining amid job stress. USA Today. Retrieved from https://www.usatoday.com/story/news/2017/10/30/surveyteachers-mental-health-declining-amid-job-stress/811577001/

University of Michigan Depression Center. (2019). Classroom mental health: A teacher's tool kit for high school [Organization's home page]. Retrieved October 6, 2019 from https://classroommentalhealth.org

U.S. Department of Health \& Human Services. (2019a, March 22). For educators [Guide with mental health resources for educators]. Retrieved from https://www.mentalhealth.gov/talk/educators

U.S. Department of Health \& Human Services. (2019b, April 5). What is mental health? Retrieved from https:/www.mentalhealth.gov/basics/what-is-mental-health 
Wang, Z., Novak, H., Scofield-Snow, H., Traylor, S., \& Zhou, Y. (2015). Am I disclosing too much? Student perceptions of teacher credibility via Facebook introduction. The Journal of Social Media in Society 4(1), 5-37. Retrieved from https://www.thejsms.org/tsmri/index.php/TSMRI/article/view/22/49

Weiss, S., \& Houser, M. (2007). Student communication motives and interpersonal attraction toward instructor. Communication Research Reports, 24(3), 215-224. doi:10.1080/08824090701439091

Wells, K. (2017). Sexual minority teachers as activist-educators for social justice. Journal of LGBT Youth, 14(3), 266-295. doi:10.1080/19361653.2017.1324344

West, M. S., \& Martin, M. M. (2019). Students' perceptions of instructor appropriateness and humor homophily. Communication Education, 68(3), 328-349. doi: $10.1080 / 03634523.2019 .1608368$

White, M. A., Whittaker, S. D., Gores, A. M., \& Allswede, D. (2019). Evaluation of a self-care intervention to improve student mental health administered through a distance-learning course. American Journal of Health Education, 50(4), 213-224.

doi:10.1080/19325037.2019.1616012

White, R. (2007). Instructor disclosure of mental illness in the social work classroom. Social Work Forum, 40/41, 127-142. Retrieved from http://connection.ebscohost.com/c/articles/31409191/instructor-disclosure-mental-illnesssocial-work-classroom

Wiedenhoeft, J. S. (2007). College students' perception of self-disclosure in the studentinstructor relationship (Master's thesis, University of Wisconsin--Whitewater). Retrieved from http://digital.library.wisc.edu/1793/79387 
Wood, B. T., Bolner, O., \& Gauthier, P. (2014). Student mental health self-disclosures in classrooms: Perceptions and implications. Psychology Learning and Teaching, 13(2), 8394. doi:10.2304/plat.2014.13.2.83

Wright, A. M. (2013). Communicating disabilities: Examining the relationship between students and accommodations and instructor self-efficacy in complying with accommodations (Master's thesis). Retrieved from Milner Library. (milner.1694709)

Wright, K. (2000). Perceptions of on-line support providers: An examination of perceived homophily, source credibility, communication and social support within on-line support groups. Communication Quarterly, 48(1), 44-59. doi:10.1080/01463370009385579 
APPENDIX A: “NO DISCLOSURE SYLLABUS” STIMULUS (NULL STIMULUS)

DIRECTIONS: Read the following sample from a COM 110 instructor's syllabus. After reading, you will be prompted to answer questions regarding said syllabus.

COMMUNICATION AS CRITICAL INQUIRY (COM 110)

\begin{tabular}{lllc}
\hline Instructor: & Jordan Wright & Office Hours: & M/W/F 1-2 PM \\
Office: & Fell 427 & Phone: & 123-456-7890 \\
Email: & jwright123@ilstu.edu & Section: & 012 \\
Classroom: & Fell 158 & Meeting time: M/W/F 10:00 AM \\
& & & \\
\hline
\end{tabular}

\section{TEXTS:}

Simonds, C. J., Hunt, S. K., \& Simonds, B. K. (2018). Engaging communication. Southlake, TX: Fountainhead Press.

\section{COMMUNICATION AS CRITICAL INQUIRY (COM 110) COURSE GOALS:}

Communication as Critical Inquiry (COM 110) seeks to improve students' abilities to express themselves and to listen to others in a variety of communication settings. The course emphasizes participation in a variety of communication processes to develop, reinforce, and evaluate communication skills appropriate for public, small group, and interpersonal settings. In short, the course is designed to make students competent, ethical, critical, confident, and information literate communicators.

\section{COURSE POLICIES:}

Cheating/Plagiarism. Students are expected to be honest in all academic work, consistent with the academic integrity policy as outlined in the Code of Student Conduct. All work is to be 
appropriately cited when it is borrowed, directly or indirectly, from another source. Unauthorized and unacknowledged collaboration on speech topics and/or the presentation of someone else's work warrants plagiarism, as does self-plagiarism.

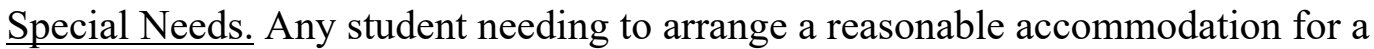
documented disability and/or medical/mental health condition should contact Student Access and Accommodation Services at 350 Fell Hall, (309) 438-5853, or visit the website at StudentAccess.IllinoisState.edu. 


\section{APPENDIX B: "PARTIAL DISCLOSURE SYLLABUS" STIMULUS}

DIRECTIONS: Read the following sample from a COM 110 instructor's syllabus. After reading, you will be prompted to answer questions regarding said syllabus.

COMMUNICATION AS CRITICAL INQUIRY (COM 110)

$\begin{array}{lllc}\text { Instructor: } & \text { Jordan Wright } & \text { Office Hours: M/W/F 1-2 PM } \\ \text { Office: } & \text { Fell } 427 & \text { Phone: } & \text { 123-456-7890 } \\ \text { Email: } & \text { jwright123@ilstu.edu } & \text { Section: } & 012 \\ \text { Classroom: } & \text { Fell 158 } & \text { Meeting time: M/W/F 10:00 AM }\end{array}$

\section{TEXTS:}

Simonds, C. J., Hunt, S. K., \& Simonds, B. K. (2018). Engaging communication. Southlake, TX: Fountainhead Press.

\section{COMMUNICATION AS CRITICAL INQUIRY (COM 110) COURSE GOALS:}

Communication as Critical Inquiry (COM 110) seeks to improve students' abilities to express themselves and to listen to others in a variety of communication settings. The course emphasizes participation in a variety of communication processes to develop, reinforce, and evaluate communication skills appropriate for public, small group, and interpersonal settings. In short, the course is designed to make students competent, ethical, critical, confident, and information literate communicators.

\section{COURSE POLICIES:}

Cheating/Plagiarism. Students are expected to be honest in all academic work, consistent with the academic integrity policy as outlined in the Code of Student Conduct. All work is to be 
appropriately cited when it is borrowed, directly or indirectly, from another source. Unauthorized and unacknowledged collaboration on speech topics and/or the presentation of someone else's work warrants plagiarism, as does self-plagiarism.

Special Needs. Any student needing to arrange a reasonable accommodation for a documented disability and/or medical/mental health condition should contact Student Access and Accommodation Services at 350 Fell Hall, (309) 438-5853, or visit the website at StudentAccess.IllinoisState.edu.

Mental Health Resources. Life at college can get very complicated, for both students and teachers alike. According to recent research, nearly $40 \%$ of college students are at-risk for developing generalized anxiety disorder and are less likely to seek help for it compared to other mental health issues. Students and teachers sometimes feel overwhelmed, lost, experience depression, and struggle with relationship difficulties or diminished self-esteem. However, many of these issues can be effectively addressed with a little help. Student Counseling Services (SCS) helps students cope with difficult emotions and life stressors. Student Counseling Services is staffed by experienced, professional psychologists and counselors, who are attuned to the needs of college students. The services are FREE and completely confidential. Find out more at Counseling.IllinoisState.edu or by calling (309) 438-3655. 


\section{APPENDIX C: “FULL DISCLOSURE SYLLABUS” STIMULUS}

DIRECTIONS: Read the following sample from a COM 110 instructor's syllabus. After reading, you will be prompted to answer questions regarding said syllabus.

COMMUNICATION AS CRITICAL INQUIRY (COM 110)

$\begin{array}{lllc}\text { Instructor: } & \text { Jordan Wright } & \text { Office Hours: M/W/F 1-2 PM } \\ \text { Office: } & \text { Fell } 427 & \text { Phone: } & \text { 123-456-7890 } \\ \text { Email: } & \text { jwright123@ilstu.edu } & \text { Section: } & 012 \\ \text { Classroom: } & \text { Fell 158 } & \text { Meeting time: M/W/F 10:00 AM }\end{array}$

\section{TEXTS:}

Simonds, C. J., Hunt, S. K., \& Simonds, B. K. (2018). Engaging communication. Southlake, TX: Fountainhead Press.

\section{COMMUNICATION AS CRITICAL INQUIRY (COM 110) COURSE GOALS:}

Communication as Critical Inquiry (COM 110) seeks to improve students' abilities to express themselves and to listen to others in a variety of communication settings. The course emphasizes participation in a variety of communication processes to develop, reinforce, and evaluate communication skills appropriate for public, small group, and interpersonal settings. In short, the course is designed to make students competent, ethical, critical, confident, and information literate communicators.

\section{COURSE POLICIES:}

Cheating/Plagiarism. Students are expected to be honest in all academic work, consistent with the academic integrity policy as outlined in the Code of Student Conduct. All work is to be 
appropriately cited when it is borrowed, directly or indirectly, from another source. Unauthorized and unacknowledged collaboration on speech topics and/or the presentation of someone else's work warrants plagiarism, as does self-plagiarism.

Special Needs. Any student needing to arrange a reasonable accommodation for a documented disability and/or medical/mental health condition should contact Student Access and Accommodation Services at 350 Fell Hall, (309) 438-5853, or visit the website at StudentAccess.IllinoisState.edu.

Mental Health Resources. Life at college can get very complicated, for both students and teachers alike. According to recent research, nearly $40 \%$ of college students are at-risk for developing generalized anxiety disorder and are less likely to seek help for it compared to other mental health issues. We all sometimes feel overwhelmed, lost, experience depression, and struggle with relationship difficulties or diminished self-esteem. I, myself, have lived and coped with a generalized anxiety disorder and a moderate depressive disorder for almost a decade now and still can have my bad days. However, these issues oftentimes can be effectively addressed with a little help. One resource I have found particularly useful in the past is Student Counseling Services (SCS), which helps students cope with difficult emotions and life stressors. Student Counseling Services is staffed by experienced, professional psychologists and counselors, who are attuned to the needs of college students. I can attest to the strides this department takes to help everyone to the best of their abilities, as they were often a great help during my time as an undergraduate student. The services are FREE and completely confidential. Find out more at Counseling.IllinoisState.edu or by calling (309) 438-3655. 


\section{APPENDIX D: NO DISCLOSURE STIMULUS MANIPULATION CHECK FORM}

DIRECTIONS: Please do not write your name on this sheet of paper. Your responses should remain anonymous. Read the following passage from an instructor's syllabus and answer the question at the end of the passage:

"Mental Health Resources. Life at college can get very complicated. According to recent research, nearly $40 \%$ of college students are at-risk for developing generalized anxiety disorder and are less likely to seek help for it compared to other mental health issues. Students sometimes feel overwhelmed, lost, experience depression, and struggle with relationship difficulties or diminished self-esteem. However, many of these issues can be effectively addressed with a little help. Student Counseling Services (SCS) helps students cope with difficult emotions and life stressors. Student Counseling Services is staffed by experienced, professional psychologists and counselors, who are attuned to the needs of college students. The services are FREE and completely confidential. Find out more at Counseling.IllinoisState.edu or by calling (309) 4383655."

Within the previous passage, how much did this instructor disclose about their mental health? (Check one option.)

Thank you for your assistance in this research project. Your participation is greatly appreciated! Please contact us if you would like to learn more about this project. 


\section{APPENDIX E: PARTIAL DISCLOSURE STIMULUS MANIPULATION CHECK FORM}

DIRECTIONS: Please do not write your name on this sheet of paper. Your responses should remain anonymous. Read the following passage from an instructor's syllabus and answer the question at the end of the passage:

"Mental Health Resources. Life at college can get very complicated, for both students and teachers alike. According to recent research, nearly $40 \%$ of college students are at-risk for developing generalized anxiety disorder and are less likely to seek help for it compared to other mental health issues. Students and teachers sometimes feel overwhelmed, lost, experience depression, and struggle with relationship difficulties or diminished self-esteem -- I myself have struggled in the past. However, many of these issues can be effectively addressed with a little help. Student Counseling Services (SCS) helps students cope with difficult emotions and life stressors. Student Counseling Services is staffed by experienced, professional psychologists and counselors, who are attuned to the needs of college students. The services are FREE to all at the university and completely confidential. Find out more at Counseling.IllinoisState.edu or by calling (309) 438-3655.”

Within the previous passage, how much did this instructor disclose about their mental health? (Check one option.)

No Disclosure Partial Disclosure Full Disclosure

Thank you for your assistance in this research project. Your participation is greatly appreciated! Please contact us if you would like to learn more about this project. 


\section{APPENDIX F: FULL DISCLOSURE STIMULUS MANIPULATION CHECK FORM}

DIRECTIONS: Please do not write your name on this sheet of paper. Your responses should remain anonymous. Read the following passage from an instructor's syllabus and answer the question at the end of the passage:

"Mental Health Resources. Life at college can get very complicated for students and faculty, myself included. According to recent research, nearly $40 \%$ of college students are at-risk for developing generalized anxiety disorder and are less likely to seek help for it compared to other mental health issues. We all sometimes feel overwhelmed, lost, experience depression, and struggle with relationship difficulties or diminished self-esteem. I, myself, have lived and coped with a generalized anxiety disorder and a moderate depressive disorder for almost a decade now and still can have my bad days. However, these issues oftentimes can be effectively addressed with a little help. Student Counseling Services (SCS) helps students cope with difficult emotions and life stressors. Student Counseling Services is staffed by experienced, professional psychologists and counselors, who are attuned to the needs of college students. I can attest to the strides this department takes to help everyone to the best of their abilities, as they were often a great help during my time as an undergraduate student. The services are FREE to all at the university and completely confidential. Find out more at Counseling.IllinoisState.edu or by calling (309) 438-3655.”

Within the previous passage, how much did this instructor disclose about their mental health? (Check one option.)

No Disclosure Partial Disclosure Full Disclosure

Thank you for your assistance in this research project. Your participation is greatly appreciated! Please contact us if you would like to learn more about this project. 


\section{APPENDIX G: DEMOGRAPHICS QUESTIONNAIRE}

DIRECTIONS: Finally, we would like to get some information about you. Your answers to these questions will help us better understand the opinions you express in other sections of this questionnaire. Please answer the following questions about yourself.

1. What is your age?

2. What is your gender?

Man _ Woman __ Genderqueer/Nonbinary __ Other

3. What is your ethnic background/race?

African American/Non-Hispanic

Caucasian/Non-Hispanic

Hispanic

Asian/Pacific Islander

American Indian/Alaskan Native

Other (Please specify:

4. What is your major?

5. What is your year in school?

Freshma

Sophomore

Junior

Senior

Other 


\section{APPENDIX H: MENTAL ILLNESS PERCEPTIONS QUESTIONNAIRE}

DIRECTIONS: Please indicate below the numerical response which best represents your perception regarding the instructor that created this syllabus. There are no right or wrong answers.

1. I wish I had not learned about mental illness from this instructor.** $\begin{array}{llllllllllll}\text { Strongly Disagree } & 1 & 2 & 3 & 4 & 5 & 6 & 7 & 8 & 9 & 10 & \text { Strongly Agree }\end{array}$

2. I wish the instructor had disclosed more about their mental illness.

$\begin{array}{llllllllllll}\text { Strongly Disagree } & 1 & 2 & 3 & 4 & 5 & 6 & 7 & 8 & 9 & 10 & \text { Strongly Agree }\end{array}$

3. This instructor disclosed too much about their mental illness.**

$\begin{array}{llllllllllll}\text { Strongly Disagree } & 1 & 2 & 3 & 4 & 5 & 6 & 7 & 8 & 9 & 10 & \text { Strongly Agree }\end{array}$

4. Teachers should be able to discuss mental illness issues in the classroom. $\begin{array}{llllllllllll}\text { Strongly Disagree } & 1 & 2 & 3 & 4 & 5 & 6 & 7 & 8 & 9 & 10 & \text { Strongly Agree }\end{array}$

5. I wish this disclosure had occurred in-person, rather than in the syllabus.** $\begin{array}{llllllllllll}\text { Strongly Disagree } & 1 & 2 & 3 & 4 & 5 & 6 & 7 & 8 & 9 & 10 & \text { Strongly Agree }\end{array}$

6. I appreciated learning about this instructor and their relation to mental illness.

$\begin{array}{llllllllllll}\text { Strongly Disagree } & 1 & 2 & 3 & 4 & 5 & 6 & 7 & 8 & 9 & 10 & \text { Strongly Agree }\end{array}$

7. The stigmatization of mental health and mental illnesses is not a pressing issue in classrooms currently.**

$\begin{array}{llllllllllll}\text { Strongly Disagree } & 1 & 2 & 3 & 4 & 5 & 6 & 7 & 8 & 9 & 10 & \text { Strongly Agree }\end{array}$

8. Mental illnesses and mental health should not be discussed in the classroom.** $\begin{array}{llllllllllll}\text { Strongly Disagree } & 1 & 2 & 3 & 4 & 5 & 6 & 7 & 8 & 9 & 10 & \text { Strongly Agree }\end{array}$ 
9. Seeing the disclosure of a mental illness in the syllabus will be beneficial to my success in the classroom.

$\begin{array}{llllllllllll}\text { Strongly Disagree } & 1 & 2 & 3 & 4 & 5 & 6 & 7 & 8 & 9 & 10 & \text { Strongly Agree }\end{array}$

10. Teachers should talk more openly about mental illness in the classroom.

$\begin{array}{llllllllllll}\text { Strongly Disagree } & 1 & 2 & 3 & 4 & 5 & 6 & 7 & 8 & 9 & 10 & \text { Strongly Agree }\end{array}$

11. I think mental illnesses and mental health should be discussed positively in the classroom to reduce stigma.

$\begin{array}{llllllllllll}\text { Strongly Disagree } & 1 & 2 & 3 & 4 & 5 & 6 & 7 & 8 & 9 & 10 & \text { Strongly Agree }\end{array}$ 


\section{APPENDIX I: CLASSROOM CLIMATE (TEACHER-STUDENT INTERACTIONS) \\ QUESTIONNAIRE}

DIRECTIONS: How would you feel in this classroom? Please, indicate with an " $\mathrm{X}$ " which answer best reflects your answer for each phrase. Numbers correspond with the following answers: 1 = "I completely disagree," 2 = "I disagree," 3 = "Neutral," 4 = "I agree," and 5 = "I completely agree."

1. In this class, it would be easy for the teacher to maintain students' good behavior and order during lessons.
$-1$
$-2$
$-3$
$-4$
$-^{5}$

2. In this class, students could help deciding good climate and discipline rules for the classroom.
$-1$
$-2$
$-3$
$-4$
$-5$

3. In this class, the teacher would make us follow the rules and obey their orders.
$-1$
$-2$
$-3$
$-4$
$-5$

4. In this class, when a student does not follow a rule, the teacher would take

measures.
$-$
1

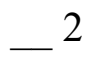
$-3$
$-4$
$-5$

5. We could give our opinion about how to organize the classroom (decoration, layout, seat display, etc.).
$-$
$-2$
$-3$
$-4$
$-5$

6. In this class, we would try to get organized to carry out activities we are interested in (raffles, trips, parties, etc.).

$-^{1} \quad-^{2} \quad-^{3} \quad-^{4} \quad-^{5}$ 
7. In this class, we would like to spend time together.

$\begin{array}{lllll}1 & -2 & -3 & -4 & -^{5}\end{array}$

8. I would feel good and comfortable in this class.

$\begin{array}{lllll}1 & -2 & -^{3} & -^{4} & -^{5}\end{array}$ 
APPENDIX J: CLASSROOM CLIMATE (ATMOSPHERE) QUESTIONNAIRE

DIRECTIONS: Please indicate below the numerical response which best represents your perception regarding the instructor that created this syllabus. There are no right or wrong answers.

1. What would your comfort level be when talking to this teacher?
Uncomfortable
$\begin{array}{lllllll}1 & 2 & 3 & 4 & 5 & 6 & 7\end{array}$
Comfortable

2. How would this teacher's classroom atmosphere feel?

$\begin{array}{llllllllll}\text { Tense } & 1 & 2 & 3 & 4 & 5 & 6 & 7 & \text { Relaxed }\end{array}$

3. How would this teacher be in class discussion?

$\begin{array}{llllllllll}\text { Judgmental } & 1 & 2 & 3 & 4 & 5 & 6 & 7 & \text { Open-Minded }\end{array}$

4. How would this teacher treat each student?
Unequally
$\begin{array}{lllllll}1 & 2 & 3 & 4 & 5 & 6 & 7\end{array}$
Equally

5. How would this teacher act toward students' problems?

$\begin{array}{llllllllll}\text { Indifferent } & 1 & 2 & 3 & 4 & 5 & 6 & 7 & \text { Sympathetic }\end{array}$

6. How would you feel before you gave your opinion in this class?**

$\begin{array}{llllllllll}\text { Encouraged } & 1 & 2 & 3 & 4 & 5 & 6 & 7 & \text { Discouraged }\end{array}$

7. Would it be easy for you to guess what this teacher would do in class?**

$\begin{array}{llllllllll}\text { Predictable } & 1 & 2 & 3 & 4 & 5 & 6 & 7 & & \text { Unpredictable }\end{array}$

8. Do you think this teacher's knowledge about the subject matter in class would be reliable?**
Reliable
$\begin{array}{lllllll}1 & 2 & 3 & 4 & 5 & 6 & 7\end{array}$
Unreliable 


\section{APPENDIX K: TEACHER CREDIBILITY QUESTIONNAIRE}

DIRECTIONS: On the scales below, indicate your feelings about the instructor that created this syllabus. Numbers 1 and 7 indicate a very strong feeling. Numbers 2 and 6 indicate a strong feeling. Numbers 3 and 5 indicate a fairly weak feeling. Number 4 indicates you are undecided.

1. I would consider this teacher to be...**

$$
\begin{array}{lllllllll}
\text { Intelligent } & 1 & 2 & 3 & 4 & 5 & 6 & 7 & \text { Unintelligent }
\end{array}
$$

2. I would consider this teacher to be...

$$
\begin{array}{lllllllll}
\text { Untrained } & 1 & 2 & 3 & 4 & 5 & 6 & 7 & \text { Trained }
\end{array}
$$

3. I would think that this teacher...**

$$
\begin{array}{lllllllll}
\text { Cares about me } & 1 & 2 & 3 & 4 & 5 & 6 & 7 & \text { Doesn't care about me }
\end{array}
$$

4. I would consider this teacher to be...**

$\begin{array}{lllllllll}\text { Honest } & 1 & 2 & 3 & 4 & 5 & 6 & 7 & \text { Dishonest }\end{array}$

5. I would think this teacher...**

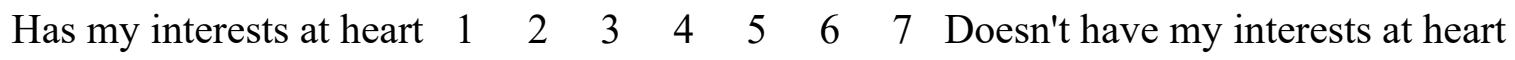
6. I would consider this teacher to be...

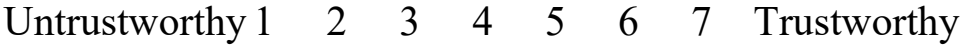

7. I would consider this teacher to be $\mathrm{a} / \mathrm{an} . .$.

$$
\text { Inexpert } \quad \begin{array}{llllllll}
1 & 2 & 3 & 4 & 5 & 6 & 7 & \text { Expert }
\end{array}
$$

8. I would consider this teacher to be...**

\section{$\begin{array}{lllllllll}\text { Self-centered } & 1 & 2 & 3 & 4 & 5 & 6 & 7 & \text { Not self-centered }\end{array}$}

9. I would think that this teacher is...**

$$
\begin{array}{lllllllll}
\text { Concerned with me } & 1 & 2 & 3 & 4 & 5 & 6 & 7 & \text { Not concerned with me }
\end{array}
$$


10. I would consider this teacher to be...**

$\begin{array}{lllllllll}\text { Honorable } & 1 & 2 & 3 & 4 & 5 & 6 & 7 & \text { Dishonorable }\end{array}$

11. I would consider this teacher to be...**

$\begin{array}{lllllllll}\text { Informed } & 1 & 2 & 3 & 4 & 5 & 6 & 7 & \text { Uninformed }\end{array}$

12. I would consider this teacher to be...**

$\begin{array}{lllllllll}\text { Moral } & 1 & 2 & 3 & 4 & 5 & 6 & 7 & \text { Immoral }\end{array}$

13. I would consider this teacher to be...

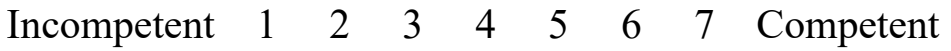

14. I would consider this teacher to be...

$\begin{array}{lllllllll}\text { Unethical } & 1 & 2 & 3 & 4 & 5 & 6 & 7 & \text { Ethical }\end{array}$

15. I would consider this teacher to be...

$\begin{array}{lllllllll}\text { Insensitive } & 1 & 2 & 3 & 4 & 5 & 6 & 7 & \text { Sensitive }\end{array}$

16. I would consider this teacher to be...**

$\begin{array}{lllllllll}\text { Bright } & 1 & 2 & 3 & 4 & 5 & 6 & 7 & \text { Stupid }\end{array}$

17. I would think that this teacher is being...

$\begin{array}{lllllllll}\text { Phony } & 1 & 2 & 3 & 4 & 5 & 6 & 7 & \text { Genuine }\end{array}$

18. I would consider this teacher to be...

$\begin{array}{lllllllll}\text { Not understanding } & 1 & 2 & 3 & 4 & 5 & 6 & 7 & \text { Understanding }\end{array}$ 


\section{APPENDIX L: BACKGROUND HOMOPHILY QUESTIONNAIRE}

DIRECTIONS: How would you feel in this classroom? Please, indicate with an " $\mathrm{X}$ " which answer best reflects your answer for each phrase about this teacher. Numbers correspond with the following answers: 1 = "I completely disagree," 2 = "I disagree," 3 = "Neutral," 4 = "I agree," and 5 = "I completely agree."

1. This teacher is from a social class similar to mine.
$-1$
$-2$
$-3$
$-4$
$-5$

2. This teacher's status is different from mine.**
$-1$

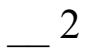
$-3$
4
$-5$

3. This teacher is from an economic situation different from mine.**

$-^{1} \quad-z^{2} \quad-^{3} \quad-^{4} \quad-^{5}$

4. This teacher's background is similar to mine.

$\begin{array}{lllll}1 & -2 & -3 & -4 & -5\end{array}$

5. This teacher's status is like mine.
$-$
$-2 \quad-3$
$-4$
$-5$

6. This teacher is from a social class different from mine.**
$-$
$-2$
$-3$
$-4$
5

7. This teacher is from an economic situation like mine.
$-1$
$-2$
$-3$
$-4$
$-5$

8. This teacher's background is different from mine.**
$-1$
$-2$
$-3$
$-4$
5

9. This teacher and I come from a similar geographic region.

$-^{1} \quad-n^{2} \quad-^{3} \quad-^{4} \quad-^{5}$ 
10. This teacher's life as a child was similar to mine.

$\begin{array}{lllll}1 & -2 & -3 & -4 & -^{5}\end{array}$

11. This teacher would be unpleasant to be around.**

$-^{1} \quad-^{2} \quad-^{3} \quad-^{4} \quad-^{5}$

12. This teacher would not be very friendly.**

$\begin{array}{lllll}-1 & -2 & -3 & -4 & -^{5}\end{array}$ 


\section{APPENDIX M: ATTITUDE HOMOPHILY QUESTIONNAIRE}

DIRECTIONS: How would you feel in this classroom? Please, indicate with an "X" which answer best reflects your answer for each phrase about this teacher. Numbers correspond with the following answers: 1 = "I completely disagree," 2 = "I disagree," 3 = "Neutral," 4 = "I agree," and 5 = "I completely agree."

1. This teacher thinks like me.

$\begin{array}{lllll}1 & -2 & -3 & -{ }^{4} & -^{5}\end{array}$

2. This teacher doesn't behave like me.**

$-^{1} \quad-^{2} \quad-^{3} \quad-^{4} \quad-^{5}$

3. This teacher is different from me.**

$\begin{array}{lllll}1 & -2 & -^{3} & -^{4} & -^{5}\end{array}$

4. This person shares my values.

$-^{1} \quad-^{2} \quad-^{3} \quad-^{4} \quad-^{5}$

5. This teacher is like me.

$-^{1} \quad-^{2} \quad-^{3} \quad-^{4} \quad-^{5}$

6. This teacher treats people like I do.

$\begin{array}{lllll}1 & -2 & -3 & -4 & -^{5}\end{array}$

7. This teacher doesn't think like me.**

$\begin{array}{lllll}1 & -2 & -3 & -4 & -^{5}\end{array}$

8. This teacher is similar to me.

$\begin{array}{lllll}1 & -2 & -3 & -{ }^{4} & -^{5}\end{array}$

9. This teacher doesn't share my values.

$\begin{array}{lllll}1 & -2 & -3 & -{ }^{4} & -^{5}\end{array}$ 
10. This teacher behaves like me.

$-^{1} \quad-^{2} \quad-^{3} \quad-^{4}-^{5}$

11. This teacher is unlike me.**

$-^{1} \quad-^{2} \quad-^{3} \quad-^{4} \quad-^{5}$

12. This teacher doesn't treat people like I do.**

$\begin{array}{rrrrr}1 & -2 & -3 & -5\end{array}$

13. This teacher has thoughts and ideas that are similar to mine.

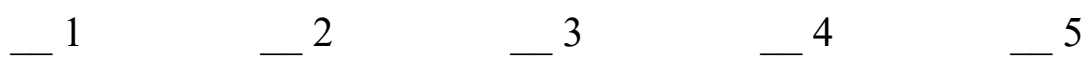

14. This teacher expresses attitudes different from mine.**

$\begin{array}{rrrr}1 & -2 & -4 & \end{array}$

15. This teacher has a lot in common with me.

$\begin{array}{rrrrr}1 & -2 & -3 & -5\end{array}$ 


\section{APPENDIX N: SOCIAL ATTRACTION QUESTIONNAIRE}

DIRECTIONS: How would you feel in this classroom? Please, indicate with an "X" which answer best reflects your answer for each phrase about this teacher. Numbers correspond with the following answers: 1 = "I completely disagree," 2 = "I disagree," 3 = "Neutral," 4 = "I agree," and 5 = "I completely agree."

1. I think this teacher could be a friend of mine.
$-$
1
$-3$
$-4$
5

2. I would like to have a friendly chat with this teacher.

$\begin{array}{llll}1 & -2 & -3 & -4\end{array}$

3. It would be difficult to meet and talk with this teacher.**

$-^{1} \quad-z^{2} \quad-^{3} \quad-^{4} \quad-^{5}$

4. We could never establish a personal friendship with each other.**

$\begin{array}{lllll}1 & -2 & -3 & -4 & -^{5}\end{array}$

5. This teacher wouldn't fit into my circle of friends. **

$\begin{array}{lllll}1 & -2 & -3 & -4 & -^{5}\end{array}$

6. This teacher would be pleasant to be with.

$\begin{array}{lllll}1 & -2 & -3 & -4 & -^{5}\end{array}$

7. This teacher would be sociable with me.

$\begin{array}{lllll}-1 & -2 & -^{3} & -^{4} & -^{5}\end{array}$

8. I would not like to spend time socializing with this teacher.**

$\begin{array}{lllll}1 & -2 & -^{3} & -^{4} & -^{5}\end{array}$

9. I could become close friends with this teacher.

$\begin{array}{lllll}1 & -2 & -^{3} & -^{4} & -^{5}\end{array}$ 
10. This teacher would be easy to get along with.

$-^{1} \quad-^{2} \quad-^{3} \quad-^{4}-^{5}$

11. This teacher would be unpleasant to be around.**

$\begin{array}{rrrr}1 & -2 & -3 & -4\end{array}$

12. This teacher would not be very friendly.**

$\begin{array}{rrrr}1 & -3 & -4 & \end{array}$ 


\section{APPENDIX O: STIMULUS QUESTIONNAIRE}

DIRECTIONS: Please indicate below the numerical response which best represents your perception regarding the instructor that created this syllabus. There are no right or wrong answers.

1. What was the level of disclosure of private information by this instructor?

$\begin{array}{llllllllllll}\text { (No Disclosure) } & 1 & 2 & 3 & 4 & 5 & 6 & 7 & 8 & 9 & 10 & \text { (Full Disclosure) }\end{array}$

2. What was the level of disclosure of mental illness by this instructor?

$\begin{array}{llllllllllll}\text { (No Disclosure) } & 1 & 2 & 3 & 4 & 5 & 6 & 7 & 8 & 9 & 10 & \text { (Full Disclosure) }\end{array}$

